Andrews University

Digital Commons @ Andrews University

1994

\title{
Improving the Understanding and Practice of Country Living in the Georgia Central Korean SDA Church
}

Martin Byung Cho Rho

Andrews University

Follow this and additional works at: https://digitalcommons.andrews.edu/dmin

Part of the Practical Theology Commons

\section{Recommended Citation}

Rho, Martin Byung Cho, "Improving the Understanding and Practice of Country Living in the Georgia Central Korean SDA Church" (1994). Professional Dissertations DMin. 635.

https://dx.doi.org/10.32597/dmin/635

https://digitalcommons.andrews.edu/dmin/635

This Project Report is brought to you for free and open access by the Graduate Research at Digital Commons @ Andrews University. It has been accepted for inclusion in Professional Dissertations DMin by an authorized administrator of Digital Commons @ Andrews University. For more information, please contact repository@andrews.edu. 


\section{ABSTRACT \\ IMPROVING THE UNDERSTANDING AND PRACTICE OF COUNTRY LIVING IN THE GEORGIA \\ CENTRAL KOREAN SDA CHURCH}

\section{by}

Martin Byung Cho Rho

Adviser: Robert M. Johnston 


\section{ABSTRACT OF GRADUATE STUDENT RESEARCH}

Project Report

Andrews University

Seventh-day Adventist Theological Seminary

Title: IMPROVING THE UNDERSTANDING AND PRACTICE OF COUNTRY LIVING IN THE GEORGIA CENTRAL KOREAN SDA CHURCH

Name of researcher: Martin B. Rho

Name and degree of faculty adviser: Robert M. Johnston, Ph.D.

Date completed: September 1993

\section{Problem}

The message of country living has been repeatedly stressed throughout the Spirit of Prophecy counsels, and there has been a problem in understanding and applying the message of country living among Korean SDA members in Korea and North America. The effect of this misunderstanding has produced many problems in the area of church growth and church leadership.

\section{Method}

This project report examined the historical background of Ellen G. White's counsels of country living and studied the writings of Ellen White regarding 
country living in relation to city mission. This study involved a workshop and survey for evaluation.

This project was primarily concerned with the religious and moral aspects of the problem and did not attempt a systematic consideration of the economic and agronomic issues, but sought to address the principles of country living, properly applying and adapting them to any given situation.

\section{Results}

The survey shows a significant change in understanding and applying Ellen White's message of country living through the workshop conducted in the Georgia Central Korean SDA Church.

\section{Conclusions}

The anti-urban attitude in the writings of Ellen G. White has significantly influenced the Adventists in North America and Korea. Ellen G. White, however, does not mean isolation from the populated cities, but a natural environment for the believers' spiritual, physical, and intellectual culture and concerns for city mission. 
Andrews University

Seventh-day Adventist Theological Seminary

IMPROVING THE UNDERSTANDING AND PRACTICE

OF COUNTRY LIVING IN THE GEORGIA

CENTRAL KOREAN SDA CHURCH

\author{
A Project Report \\ Presented in Partial Fulfillment \\ of the Requirements for the Degree \\ Doctor of Ministry
}

by

Martin Byung Cho Rho

May 1994 



\title{
IMPROVING THE UNDERSTANDING AND PRACTICE OF COUNTRY LIVING IN THE GEORGIA CENTRAL KOREAN SDA CHURCH
}

\author{
A project report \\ presented in partial fulfillment \\ of the requirements for the degree \\ Doctor of Ministry
}

by

Martin Byung Cho Rho

APPROVAL BY THE COMMITTEE:

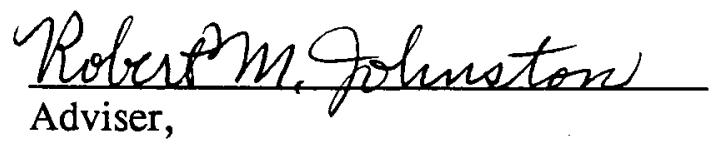

Robert M. Johnston
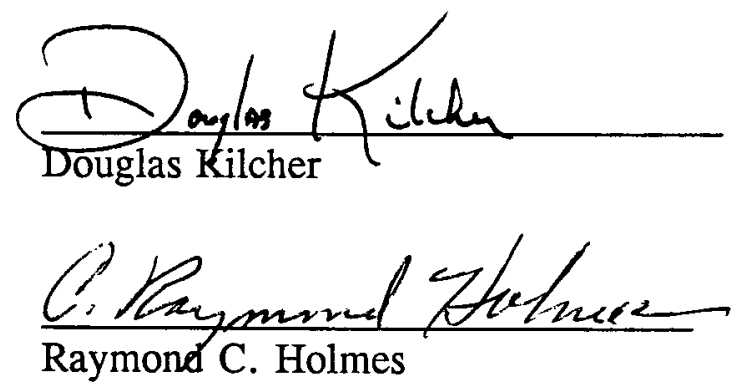

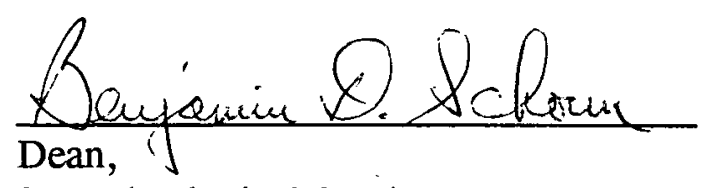

SDA theological Seminary

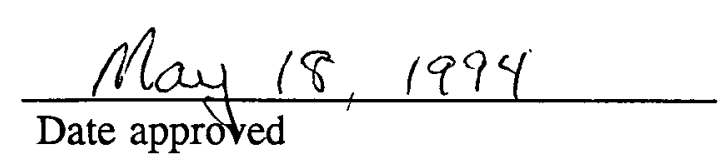




\section{DEDICATION}

To my wife Sunny for her patience, support and help throughout my doctoral program, and to the members of the Georgia Central Korean Seventh-day Adventist Church who have helped me to accomplish this project 


\section{TABLE OF CONTENTS}

ACKNOWLEDGMENTS $\ldots \ldots \ldots \ldots \ldots \ldots \ldots$ viii

Chapter

I. INTRODUCTION $\ldots \ldots \ldots \ldots \ldots \ldots \ldots \ldots \ldots \ldots \ldots$

Statement of the Problem $\ldots \ldots \ldots \ldots \ldots \ldots \ldots$

Justification of the Project . . . . . . . . . . . . 3

Methodology ................... 4

Limitations of the Project . . . . . . . . . . . . . 4

Primary and Main Secondary Sources $\ldots \ldots \ldots \ldots \ldots$

Overview .................... 5

II. HISTORICAL BACKGROUND OF THE SDA COUNTRY-

LIVING MOVEMENT $\ldots \ldots \ldots \ldots \ldots \ldots \ldots \ldots \ldots \ldots \ldots$

Urbanizing America $\ldots \ldots \ldots \ldots \ldots \ldots \ldots$

Anti-Urban Heritage in American Thought (1790-1850) . . . . . . 7

Influence of Thomas Jefferson . . . . . . . . . . . . . 7

Ralph Waldo Emerson . . . . . . . . . . . . . . . 9

American Literature Tradition . . . . . . . . . . . . . . 10

Religious Implications of the Cities . . . . . . . . . . . 12

Ecological Conception of the City . . . . . . . . . . . 12

Anti-Urban Religious Organizations in

America . . . . . . . . . . . . . . . . . . . . 13

The Amish Society in America (1727-) . . . . . . . . . 14

The Amish Charter . . . . . . . . . . . . . . . 15

Separation from the world ... . . . . . . . . 15

Closeness to nature: Agrarianism . . . . . . . . . 16

The Mennonite Community in America (1646- ) . . . . . . . . 17

Mennonite Way of Life: Rural Community . . . . . . . . . 18

Anti-Urban Heritage and Ellen G. White . . . . . . . . . . . 18

Ellen G. White and Country Living . . . . . . . . . . . . 19 
The Adventist Response in North America . . . . . . . . . . . . 23

G.I. Butler and W.W. Prescott . . . . . . . . . . . . 23

The Battle Creek Church . . . . . . . . . . . . . . 23

The Oakland Church . . . . . . . . . . . . . . . 24

The World War II Era . . . . . . . . . . . . . . . 25

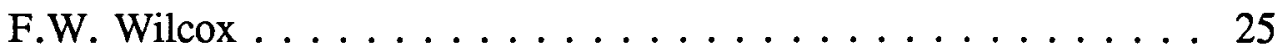

Carlyle B. Haynes . . . . . . . . . . . . . . . 26

The Committee on Country Living . . . . . . . . 27

North American Commission for

Self-Supporting Missionary Work . . . . . . . . . . . . . 27

SDA Commission on Rural Living (SDACRL) . . . . . . . . 28

The Association of SDA Self-Supporting

Institutions (ASI) $\ldots \ldots \ldots \ldots$

Educational Reform Movement Among

Seventh-day Adventists . . . . . . . . . . . . 30

Walla Walla College $(1892-$ ) . . . . . . . . . . . . . . 30

Avondale College $(1895-\quad$ ) . . . . . . . . . . . . 31

Battle Creek College $(1874-\quad$ ) . . . . . . . . . . . . . . 31

Emmanuel Missionary College $(1901-\quad) \ldots \ldots \ldots \ldots \ldots$. . . 32

Madison School (1904- ) . . . . . . . . . . . . . . 32

The Wildwood Sanitarium and Medical

Missionary Institute $(1904-\quad$ ) . . . . . . . . . . . . 33

Wildwood "outposts" . . . . . . . . . . . . . . . 33

Weimar Institute (1919- ) . . . . . . . . . . . . . . . . 34

Korean Adventist Country-Living Movement . . . . . . . . . 35

Refugee Living in the Mountains (1944-45) . . . . . . . . 35

Influence of James Lee, Hyunchul Shin, and Pyungan Kim $(1980-\quad) \ldots \ldots \ldots \ldots \ldots$

Mountain-living Group $(1959-70) \ldots \ldots \ldots$. . . . . . 37

Country Living (1970s) . . . . . . . . . . . . . . . . . . 38

Cultist, Myung Ho Park (1980- ) . . . . . . . . . . . . . . 39

III. COUNTRY LIVING AND CITY LIVING IN THE WRITINGS

OF ELLEN G. WHITE AND OTHER ADVENSTISTS . . . . . . 42

God's Original Plan: Country . . . . . . . . . . . . . 42

Physical Surroundings of Country . . . . . . . . . . 43

Country Heritage of Noble People in the Bible . . . . . . . . . 45

Adam and Eve . . . . . . . . . . . . . . 45

Issac and Joseph . . . . . . . . . . . . . . 45

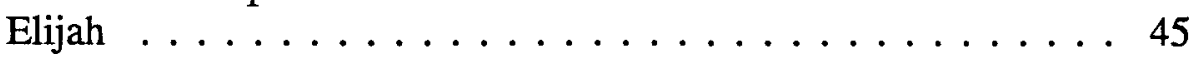

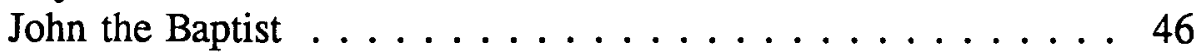

Jesus . . . . . . . . . . . . . . 46 
Question of Distance from the City for Both

Home and Institutional Location . . . . . . . . . . . . . 47

Certain Guiding Principles in Choosing a

Location for an Institution . . . . . . . . . . . . . . . . . . 49

Close Proximity to a Densely Populated

District . . . . . . . . . . . . . . . . . 49

Natural Environment and Utilities . . . . . . . . . . . . . . 50

Some Guiding Principles in Choosing a

Location for a Home ................. . 50

Religious and Moral Influence . . . . . . . . . . . . 50

A Rural Environment with Land for

Cultivation . . . . . . . . . . . . . . 51

No Fixed Rule for Everybody . . . . . . . . . . . . 52

What to Watch for in Selecting a Home

Location . . . . . . . . . . . . . . . 52

Occupations in Rural Location . . . . . . . . . . . . . . . 53

The Most Favorable Occupation . . . . . . . . . . . . 53

The Rural Home for the City Worker . . . . . . . . . . . . . 54

Owning a Business in the Country . . . . . . . . . . . 54

Conditions in the City: Reasons for Leaving the Cities . . . . . . 55

Religious and moral conditions . . . . . . . . . 56

Physical surroundings . . . . . . . . . . . . 57

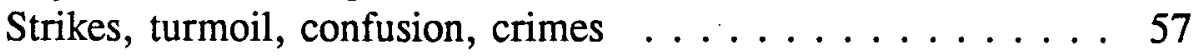

Amusement and entertainment centers .... . . . . . . 58

Large churches . . . . . . . . . . . . . . . . . 60

City: Object of God's judgement . . . . . . . . . . . . 60

A part of the three angels' message in Rev. $14 \ldots \ldots \ldots .62$

Eschatological calls . . . . . . . . . . . . . . . 63

Economic situation of the last days . . . . . . . . . . 65

Caution to Those Who Anticipate Leaving the City . . . . . 66

IV. BALANCING ACT: COUNTRY LIVING AND CITY MISSION . . 67

City Mission: An Indisputable Counsel . . . . . . . . . . 68

Brief History of the Early SDA City Mission . . . . . . . . . . 69

The vision of Ellen G. White and the Oakland experience . . . . 69

Working for the underprivileged $\ldots \ldots \ldots \ldots \ldots \ldots 71$

Dr. John Harvey Kellogg . . . . . . . . . . . . . . . . 72

Diversion of the city mission and resources . . . . . . . 75

Paradox of SDA Mission . . . . . . . . . . . . . 77

Great Needs of the Cities . . . . . . . . . . . . 77

Difficult Situation . . . . . . . . . . . . . . . 79 
Resolving the Tension ................ 80

Not either/or but both aspects of the

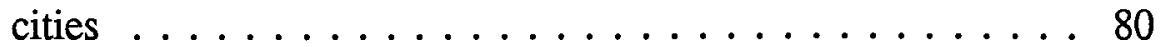

Not either/or but both without and within $\ldots \ldots \ldots . \ldots 83$

V. DESIGN AND ADMINISTRATION OF THE INTERVENTION AND ITS EVALUATION $\ldots \ldots \ldots \ldots \ldots \ldots$

Design and Administration $\ldots \ldots \ldots \ldots \ldots \ldots$

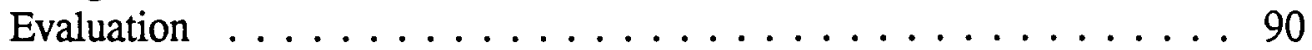

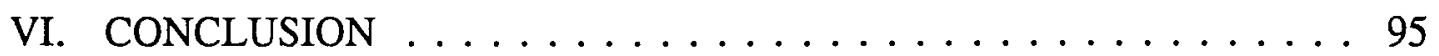

Appendix

1. QUESTIONAIRE FOR SURVEY REGARDING COUNTRY LIVING (SURVEY 1$) \ldots \ldots \ldots \ldots$. . . . . . . . . 99

2. QUESTIONAIRE FOR SURVEY REGARDING COUNTRY LIVING (SURVEY 2$) \ldots \ldots \ldots \ldots \ldots \ldots$. . . . . . . 103

3. SEVENTH-DAY ADVENTIST SELF-SUPPORTING SCHOOLS IN CURRENT OPERATION $\ldots \ldots \ldots \ldots \ldots \ldots$

4. LECTURE OUTLINE $1 \ldots \ldots \ldots \ldots \ldots \ldots$

5. LECTURE OUTLINE $2 \ldots \ldots \ldots \ldots \ldots \ldots \ldots$

6. LECTURE OUTLINE $3 \ldots \ldots \ldots \ldots \ldots \ldots \ldots$

7. GRAPH OF SURVEY STATISTICS $\ldots \ldots \ldots \ldots \ldots \ldots$

BIBLIOGRAPHY . . . . . . . . . . . . . . . . . . . . . 119

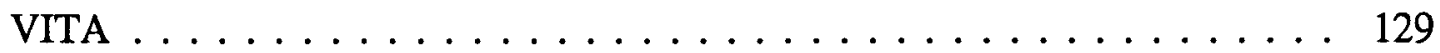




\section{ACKNOWLEDGMENTS}

I would like to acknowledge the help received from my project committee: Dr.

Robert M. Johnston, Dr. Raymond C. Holmes, Dr. Douglas Kilcher. Special thanks goes to Dr. Robert M. Johnston for his guidance as committee chairman and for his personal interest. 


\section{CHAPTER I}

\section{INTRODUCTION}

\section{Statement of the Problem}

There is within the Seventh-day Adventist (SDA) church the message of country living that has been repeatedly stressed throughout the Spirit of Prophecy counsels, ${ }^{1}$ as well as a long-standing admonition for Seventh-day Adventists to move from the cities to the country where they can live a simple and satisfying life close to nature and God. ${ }^{2}$ One of the most comprehensive statements that can be used to support this call to country living can be found in Ellen G. White's book Education:

Those who departed from God built for themselves cities, and congregating in them, gloried in the splendor, the luxury and the vice that makes the cities of today the world's pride and its curse, but the men who held fast God's principles of life dwelt among the fields and hills. They were tillers of the soil, and the keepers of flocks and herds. And in this free, independent life, with its opportunities for labor and study and meditation, they learned of God, and taught their children of His works and ways. ${ }^{3}$

${ }^{1}$ See bibliography.

${ }^{2}$ For example, Ellen G. White, Country Living: An Aid to Moral and Social Security (Washington, DC: Review and Herald Publishing Association, 1946); Arthur L. White and E. A. Sutherland, From City to Country Living (Hagerstown, MD: Review and Herald Publishing Association, 1983).

${ }^{3}$ Ellen G. White, Education (Mountain View, CA: Pacific Press Publishing Association, 1903), 34. 
Many Adventists, therefore, have considered this message seriously as a prominent theme in their piety and idealogy, and have started country-living movements in the setting of educational reform movements such as the Madison School started in $1904,{ }^{1}$ Wildwood Institute, $1941,{ }^{2}$ and Weimar Institute, 1977. ${ }^{3}$

This, however, tends to create a difficult environment for church growth in Korea and Korean churches in North America, as it has been shown that the countryliving movement in the 1960s and 1970s in Korea, ${ }^{4}$ and in the 1970s in Atlanta, Georgia $^{5}$, have led many families to leave local churches to live in the mountains, and that, after a few years, these groups have been dissolved.

Another group was formed by two former denominational pastors near Athens, Georgia, in 1988, and they have called believers out of the established congregations and urged them to join them in the country. This group, like the previous groups, has set dates for the enforcement of the Sunday law in 1991, and for Jesus' second coming in 1992, etc. In addition, they do not send their children to

'Ira Gish and Harry Christman, Madison: God's Beautiful Farm: The E. A. Sutherland Story (Mountain View, CA: Pacific Press, 1974), 102.

${ }^{2}$ Wildwood Historical Sketch (Wildwood, GA: Wildwood Sanitarium, 1974), 4, Ellen G. White Research Center, Andrews University, Berrien Springs, MI (EGWRC-AU), Document File 357-d.

${ }^{3}$ Robert H. Pierson, Miracles Happen Every Day (Mountain View, CA: Pacific Press, 1983), 36.

${ }^{4}$ Sang Do Kim, "Report of Dosari, Ichun Meeting," Church Compass (Seoul, Korea: Korean Signs of the Times Publishing House, 1968), 6.

${ }^{5}$ This group, formed by a denominational pastor, purchased land for the group country living in Auburn, Georgia. 
public or private schools, but teach them at home. This group even blames and criticizes the church and its leadership for lack of interest in country living according to their standards. The negative and unsettling impact of this group has reached far and wide, even to Korea. Families from many Korean churches in North America have moved to Lavonia, Georgia, and have formed "a church within a church." ${ }^{1}$

\section{$\underline{\text { Justification of the Project }}$}

While there is considerable documentation for country living, much of it is scattered and fragmentary (along with two books). ${ }^{2}$

This, I believe, is not satisfactory to meet the urgent need of presenting to the congregation a clarification of country living in order to unify thinking about its application.

Tension exists among the Seventh-day Adventists tension between the ethos of country living and insights of the church-growth movement in view of the rapid urbanization of modern society. ${ }^{3}$ There is a need for a check and balance between these two essential necessities in order to effect a "balancing act. ${ }^{14}$

'Term used in The Seventh-day Adventist Church and Certain Private Ministries (Silver Spring, MD: North American Division, 1992), 15.

${ }^{2}$ Ellen G. White, Country Living: An Aid to Moral and Social Security; Arthur L. White and E. A. Sutherland, From City to Country Living.

${ }^{3}$ Gottfried Oosterwal, "God Loves the Cities," Adventist Review, February 5, 1987, 8-10; William D. Frazee, "Out of the Cities: A Part of the Three Angels' Messages, " n.p.: n.d. Adventist Heritage Center, Andrews University, Berrien Springs, MI (hereafter referred as AHC-AU).

$1990,5$.

${ }^{4}$ Kit Watts uses the term in "Balancing Acts," Adventist Review, August 9, 


\section{Methodology}

This project report examines the writings of Ellen G. White regarding country living as a primary source, and suggests a genuine application of the message. It involves an intervention in the form of a workshop.

This report focuses on (1) the historical background of the country-living movement in the Seventh-day Adventist church, (2) principles of country living suggested by Ellen G. White, and (3) the relationship between city mission and country living. A survey was done before and after the workshop to see if any change in the thinking of workshop participants occurred. The workshop and survey were conducted at the Georgia Central Korean SDA Church which is located in the north eastern part of Atlanta, Georgia. Forty two out of one hundred thirty two church attendants, participated in the workshop.

\section{Limitations of the Project}

This report is concerned primarily with the religious and moral aspects of the problem and does not attempt a systematic consideration of the economic and agronomic issues. Obviously, there is no fixed rule for everyone in the counsels for country living. ${ }^{1}$ This report, therefore, seeks to address the principles for properly applying and adapting to any given situation.

\section{Primary and Main Secondary Sources}

Besides the books and articles written by Ellen $\mathrm{G}$. White, the primary

${ }^{1}$ White and Sutherland, From City to Country Living, 19-20. 
sources for this project included Ellen G. White's unpublished manuscripts and letters in the Ellen G. White Research Center, Andrews University, Berrien Springs, Michigan. ${ }^{1}$ Main secondary sources were the compilations from the writings of Ellen G. White and the books and unpublished papers written by Adventist thinkers other than Ellen G. White. These unpublished papers are in the Adventist Heritage Center, Andrews University, Berrien Springs, Michigan. ${ }^{2}$

\section{Overview}

This project consists of several sections in addition to this introduction. Chapter 2 deals with the anti-urban heritage in American thought as historical background of the country-living movement in the Seventh-day Adventist church. Chapter 3 examines what "city" and "country" are meant by Ellen G. White, in addition to reasons, cautions, and timing for moving to the country, and city missions. Chapter 4 discusses the great needs of the cities in relation to country living. Chapter 5 evaluates the intervention by workshop and presents some recommendations.

\footnotetext{
${ }^{1}$ Hereafter referred to as EGWRC-AU.

${ }^{2} \mathrm{Hereafter}$ referred to as AHC-AU.
} 


\section{CHAPTER II}

\section{HISTORICAL BACKGROUND OF THE SDA COUNTRY-LIVING MOVEMENT}

This chapter presents the history of the country-living movement in America as a background of the SDA country-living movement and describes its manifestation and influence in American and Korean Adventistism.

\section{Urbanizing America}

The story of American urbanization as outlined by the statistics of growth has shown a decreasing percentage of the total population living in rural areas since the early decades of U.S. history. As late as 1790 , the first federal census revealed that only 5.1 percent of the population lived in towns. For the next thirty years the proportion remained fairly stable, rising to about 6 percent in 1800 , to 7.3 in 1810 , and then dropping to 7.2 percent in 1820. After 1820, the figure begins to rise significantly. The urban population grew three times as fast as the total population grew during every decade between 1810 and 1860 . In 1820 , the country contained only 12 cities with populations larger than 10,000 , but by 1860 , there were 101 such 
cities, including 8 which had passed the 100,000 mark and 1 which exceeded a million. ${ }^{1}$

The U.S. census of 1990 showed that 77 percent of the population lives in metropolitan areas. Approximately 50 percent of Adventists live in metropolitan areas, and 50 percent live in small towns and rural areas. ${ }^{2}$

\section{Anti-Urban Heritage in American \\ Thought (1790-1850)}

During the early years of the American nation, reaction to the country's rapidly growing cities was inconsistent and often contradictory. For example, spokesmen of the South and West might attack the cities of the eastern seaboard as the seats of national evil and corruption, yet defend their own cities as representing the highest ideals of a republican civilization. Sentiments and interests influenced early nineteenth-century attitudes toward cities and their meaning in American life. ${ }^{3}$

\section{Influence of Thomas Jefferson}

As early as 1784 , when American cities were little more than towns, Thomas Jefferson often explicitly asserted that those who labored in the earth were

${ }^{1}$ Charles N. Glaab and A. Theodore Brown, A History of Urban America (New York: Macmillan Company, 1967), 25-26.

${ }^{2}$ North American Division of SDA Church Information System (Monte Sahlin, Project Coordinator), Report 1, Adventist Family Opinion: Demographic Profile, 1990.

${ }^{3}$ Glaab and Brown, A History of Urban America, 53-54. 
the chosen people of God. "The mobs of great cities," he continued, "add just so much to support of pure government as sores do to the strength of the human body. ${ }^{11}$

Jefferson considered the cities a threat to the future of American democracy--an agricultural economy. He granted that the city was necessary for commerce and the arts and science, but he believed cities could not rival the country for producing real men. During his travels in Europe from 1784-1789, Jefferson observed the deplorable conditions and "empty bustle" of European cities, which "reinforced his belief that cities represented a threat to American values." In a subsequent letter to James Madison in 1787, Jefferson reflected: "I think our government will remain virtuous for many centuries as long as they are chiefly agricultural. . . . When they get piled upon one another in large cities, as in Europe, they will become corrupt as in Europe." 2

Jefferson's most bitter observation on American cities was reflected in a comment to Benjamin Rush in 1800 on yellow fever epidemics:

When great evils happen I am in the habit of looking out for what good may arise from them as consolations to us, and Providence has in fact so established the order of things, as most evils and the means of producing some good. The yellow fever will discourage the growth of great cities in our nation, and I view great cities as pestilential to the morals, the health and the liberties of men. ${ }^{3}$

After 1820, Jefferson feared large American cities, which grew in part through the manufacturing boom, and advised, rather than building manufacturing centers in

${ }^{1}$ Thomas Jefferson, quoted in Glaab and Brown, 55.

${ }^{2}$ Ibid.

${ }^{3}$ Ibid. 
American cities, "for the general operations of manufacture, let our workshops remain in Europe." 1

Thomas Jefferson's view of the city rested on assumptions about humanity and the world that at least went back to Virgil's Georgics and to Adam Smith, who had found "unnaturalness and dependence" to be urban dwellers' vices and had argued that "to cultivate the ground was the natural destination of man."2

In much of the early nineteenth-century American thought, the city was looked upon as an artificial institution that might be corruptive to the elemental man or woman.

\section{Ralph Waldo Emerson}

The transcendentalist philosopher, Ralph Waldo Emerson, argued "the need of man to return to the woods." He wrote to Thomas Carlyle in 1840: "I always seem to suffer some loss of faith on entering cities. ${ }^{13}$ In a late essay on farming and the farmer, Emerson went farther:

That uncorrupted behavior which we admire in animals and in young children belongs to ... the man who lives in the presence of nature. Cities force growth and make men talkative and entertaining, but they make them artificial. ${ }^{4}$

${ }^{1}$ Thomas Jefferson, quoted in Morton White and Lucia White, The Intellectual Versus the City (Cambridge: Harvard University Press, 1962), 55.

${ }^{2}$ Glaab and Brown, A History of Urban America, 55.

${ }^{3}$ Ibid., 60.

${ }^{4}$ Ibid., 53. 


\section{American Literature Tradition}

The American literature tradition inherited old prejudices against the city. Strains of Hebraic agrarianism in Christian thought, which pictured the city as the home of vanity, carnal lust, and conspiracy, often gave an anti-urban cast to American religious writing. ${ }^{1}$

Themes of the evil city are dominant in the first important American novel, Charles Brockden Brown's Arthur Mervyn (1799). As Morton and Lucia White have observed, the American literary tradition has often been about anti-urban sentiments. A dominant theme in the fiction of that period is that of America as the lost Eden. The city becomes the symbol of the fall from grace of the land and its people. ${ }^{2}$

Harry Levin depicted that "America was a garden, an agrarian Eden, which was losing its influence by becoming citified."

Nathaniel Hawthorne believed that cities are "fascinating" but "dangerous," and that Boston could induce bad dreams in My Kinsman and Major Molineux. The pre-revolution setting pictures Robin, a young country boy, searching for future prosperity through a wealthy relative, Major Molineux. Arriving at night, he feels "a sensation of loneliness stronger than he had ever felt in the remotest depths of his native woods." Walking through the deserted streets, he meets some thugs and encounters a prostitute. After several ghastly experiences, he falls asleep and dreams
${ }^{1}$ Ibid., 53.
${ }^{2}$ Ibid., 61.
${ }^{3}$ White and White, The Intellectual Versus the City, 36. 
that he finally meets his wealthy relative. In the ensuing nightmare he sees the humiliated Major, who has been tarred and feathered, pulled through the streets of Boston by a frantic mob. When Robin awakes, he has seen enough. "Will you be kind enough to show me the way to the ferry? I begin to grow weary of town life."1

The haunting portrayal of city life was also a favorite theme for Edgar Allen Poe in his The Doomed City and The City of Sin. These pieces, to mention only a few, revealed the worst in cities like London, Liverpool, Paris, or Rome. ${ }^{2}$ But the prophetic transfer of Europe's present condition to America's future moved Hawthorne to write: "All towns should be made capable of purification by fire, or of decay, within each half-century." ${ }^{3}$

Themes of the evil city were also vividly reflected in sensational works on the sinful metropolises of America as early the 1840s. Osgood Bradbury in his The Bell of the Bowery (1846), Female Depravity or The House of Death (1852) developed the story of the innocent country girl who is led into evil ways in the city. ${ }^{4}$ Henry David Thoreau expresses his love of nature in his book Walden. In this book Thoreau confronts the natural world on his terms. For example, the chapter "The Ponds" portrays his anti-urban perspectives. Thoreau states: "Sometimes,
${ }^{1}$ Ibid., 14.
${ }^{2}$ Ibid., 43-46.
${ }^{3}$ Ibid., 53.
${ }^{4}$ Glaab and Brown, A History of Urban America, 63. 
having had a surfeit of human society and gossip, and worn out all my village friends, I rambled still farther westward than I habitually dwell . . . 'to fresh woods and pastures new.'"1

\section{Religious Implications of the}

$\underline{\text { Cities }}$

Religious studies of the city in America offered a related view--that the city could serve as the testing ground for the faith of a Christian. For example, Amory D. Mayo in Symbols of the Capital; a Civilization in New York (1859) seems to examine American urban life with a balanced point of view in that he attacked the city with all its materialistic trends, while not denying the positive reality of the city. He observed the people flocking into cities and being challenged by experience, and thought their faith and character could be strengthened if they survived the evils of the city. $^{2}$

The religious argument that the city provides a way of strengthening Christian ideals, but that the American city with its extremes of wealth and poverty, its materialism, and its exploitation contradicted Christian principles, worked its way into a substantial body of pre-Civil War writing about urban life.

${ }^{1}$ Henry David Thoreau, Walden and Civil Disobedience (New York: W. W. Norton \& Company, 1966), 116. See also Carl Bode, ed., The Portable Thoreau (New York: Viking Press, 1947).

${ }^{2} \mathrm{Ibid} ., 66$. 


\section{Ecological Conception of the}

City

Observation tends to support the concept that the city was essentially unhealthy, a dangerous type of environment that threatened humankind's physicalexistence, for it was largely city dwellers who were struck down by the frequent, dreaded nineteenth-century plagues of cholera, yellow fever, and other diseases.

Many diseases, particularly epidemic in nature, were regarded not as entities but as dynamic conditions such as moral, climatic, and environmental factors, until the 1880 s when the germ theory of disease was generally accepted in the United States.

Jefferson devised a plan to remove disease-causing vapors from American cities. American intellectuals from Thomas Jefferson to Frank L. Wright ${ }^{1}$ feared the city in a physical sense--as the source of dangerous contaminating exhalations. ${ }^{2}$

The notion of an individual city as an organic structure subject to inevitable decay because of its production of pervasive disease-producing vapors absorbed many writers concerning the American future. ${ }^{3}$

\section{Anti-Urban Religious Organizations in America}

A number of religious organizations sought to plant more of their members in the country for evangelism in the 1950s. The Roman Catholic church was

\footnotetext{
${ }^{1}$ See White and White, The Intellectual Versus the City.

${ }^{2}$ Ibid., 68-69.

${ }^{3}$ Ibid., 71 .
} 
especially active in sending families into rural areas where they had few members in order to propagate their faith. ${ }^{1}$ In 1953 , C. R. McBride, professor of rural leadership training at Central Baptist Theological Seminary, promoted rural living by writing a book, The Christian Home in a Rural Setting ${ }^{2}$, which harmonizes in many points with the counsel given by Ellen G. White.

However, the Mennonite and Amish societies in America have been, from the beginning of their organizations, believers in rural living as the way of life for families. Assuming these two communities have to some degree influenced the American religious thought toward anti-urban sentiments, their history and lifestyle is briefly discussed to show the similarities as well as dissimilarities between these two communities and the counsels of Ellen G. White.

The Amish Society in America $\underline{(1727-)}$

The Amish, as a distinct cultural group that has been in the United States for over two centuries, still stand out sharply as a people who have maintained strong group identity. The Amish, taking their name from their leader Jakob Ammaan, are descendants of a religious division that occurred among the Swiss Anabaptists between 1693 and 1697.

${ }^{1}$ Wesley Amundsen, review of The Christian Home in a Rural Setting, by C. R. McBride, in Ministry, April 1954, 45-46.

${ }^{2}$ C. R. McBride, The Christian Home in a Rural Setting (Philadelphia, PA: Judson Press, 1953). 
The Amish people came to Pennsylvania from Switzerland as early as 1727, and made Lancaster County, Pennsylvania, the center of Amish life, distinguished as the garden spot of the nation. There are today no Amish in Europe who have retained the name and principles of the original group. ${ }^{1}$

\section{The Amish Charter}

The moral principles of the contemporary Amish community are embodied in the Amish charter. Amish life and behavior are oriented to absolute values, involving a conscious belief in religious and ethical ends. The Amish view of reality is conditioned by a dualistic worldview: light and truth coexist with the powers of darkness and falsehood; purity and goodness are in conflict with impurity and evil. The dualistic conception of reality is the ground for their rejection of the world. ${ }^{2}$

\section{Separation from the world}

Based upon the notion that there is a divine spiritual reality, the Kingdom of God, and a Satanic Kingdom that dominates the present world, the duty of Christians is to keep themselves "unspotted from the world" and separate from the desires, intent, and goals of the worldly person.

The Amish often quote two passages of the Bible. The first is: "Be not conformed to this world, but be ye transformed by the renewing of your mind that ye may prove what is that good and acceptable and perfect will of God" (Rom 12:1). To 1963), 38.

${ }^{1} \mathrm{John}$ A. Hostetler, Amish Society (Baltimore, MD: Johns Hopkins Press, ${ }^{2}$ Ibid., 47-48. 
the Amish, this text means among other things that one should not dress and behave like the world. The second is: "Be ye not equally yoked together with unbelievers; for what fellowship hath righteousness with unrighteousness? And what communion hath light with darkness" (2 Cor 6:14). ${ }^{1}$ This strong belief forbids working in cities or factories, and using electricity, telephone, central-heating systems, and automobiles. Horses are used for farming and travel. ${ }^{2}$

Closeness to nature: Agrarianism

The Amish community has a strong affinity for the soil and for nature, based on the worldview that the physical world is good, and in itself, not corrupting or evil.

The charter of Amish life requires members to limit their occupation to farming or closely associated activities such as operating a saw mill, carpentry, or mason work. The preference for rural living is reflected in attitudes and in the informal relations of group life, rather than in an explicit dogma. ${ }^{3}$

One Amish said, "The Lord told Adam to replenish the earth and to rule over the animals and the land--You can't do that in cities." Another said, "While the Lord's blessings were given to the people who remained in the country, sickness and ruination befell Sodom. ${ }^{14}$
${ }^{1}$ Ibid., 59-61.
${ }^{2}$ Ibid., 48-51.
${ }^{3}$ Tbid., 6.
${ }^{4}$ Tbid., 67. 
The Amish attribute their material success in farming to divine blessing. The main objective of their farming "is to accumulate sufficient means to buy enough land to keep all the children on farms. To this end the Amish work hard, produce abundantly, and save extensively."1

\section{The Mennonite Community in} America (1646-)

Menno Simon joined the peaceful Anabaptists in January 1536 through the itinerant preacher Melchior Hoffman. Because of Menno's capable leadership, the Anabaptists in the north soon gained the nickname "Mennonite." The name "Mennonites" was later applied generally to include descendants of both Swiss and Dutch Anabaptists. From the Netherlands, many Mennonites migrated to northern Germany, Prussia, Russia, and later to the central plains of the United States. Dutch Mennonites came to Manhattan (New York) as early as in 1644 and to Long Island (New York) in $1657 .^{2}$

From these early beginnings, European and Russian Mennonites settled in the United States, and they naturally brought with them a variety of cultural forms and religious concerns. Most Mennonites came to the United States and Canada to escape European intolerance and persecution.

\footnotetext{
${ }^{1}$ Walter Kollmorgen, Culture of a Contemporary Community: The Old Order Amish of Lancaster County, Pennsylvania Washington, DC: (United States Department of Agriculture, 1942), 30.

${ }^{2}$ Cornelius J. Dyck, ed., An Introduction to Mennonite History (Scottdale, PA: Herald Press, 1967), 188-207.
} 
Mennonite Way of Life: Rural

Community

For many Mennonites, non-Mennonites were a threat to their faith, necessitating withdrawal from the "world" with its temptations and sin. From the religious perspective of life, the Mennonites considered the agricultural economy as ideal. For three hundred years, farming was considered to be the Mennonite way of life and the rural community the indispensable form of organizing their common life. To be a Mennonite almost invariably meant to grow up in an agricultural community. So strong was this heritage that many believed Mennonites could not survive in the cities. $^{1}$

Following World War II, however, this unique way of life began to change in order to cope with the rapid urbanization in North America. Their movement to the cities and consequent shift in the vocations of many Mennonites tested their faith and moral values in a new way. ${ }^{2}$

\section{Anti-Urban Heritage and Ellen G. White}

It is impossible to determine how this anti-urban heritage related with the thought of Ellen G. White on rural living. But even if the anti-urban attitude of contemporary intellectuals was not directly transferred to the early Adventists, ${ }^{3}$ it

${ }^{1}$ Ibid., 400-401.

${ }^{2}$ Ibid., 402.

${ }^{3}$ Gottfried Oosterwal says that the anti-city attitude of Adventists, especially in North America, is rooted partly in cultural heritage of the nineteenth-century American frontier. See Oosterwal, "God Loves the Cities," 8. 
seems that Ellen G. White was influenced by moralistic "strains of Hebraic agrarianism in Christian thought, which pictured the city as the home of vanity, carnal lust, and conspiracy."1

The building of cities by the descendants of Cain (Gen 4:17), the call of Abram out of Ur (Gen 12:1), and the attractiveness of Sodom to Lot and his wife (Gen 19) were frequently used illustrations and warnings of a direct relationship between city life and evil.

Seventh-day Adventism began and remained predominantly rural in membership until the early 1870 s when an era of city building began. Ellen $\mathrm{G}$. White (1827-1915), the major proponent of country living, was born and later died on a farm. Despite her constant travel, she with her husband developed three small farms, and in Australia, she supervised the development of an agricultural program at Avondale College. Her writings reveal over sixty separate statements on city versus country living. Beginning around 1870 and continuing through 1910 , her vigorous denouncements of the city, and on the other hand, her positive testimony to country life, became more urgent and dramatic.

\section{Ellen G. White and Country}

Living

Ellen G. White's earliest published statement on country living appeared in 1870. Her early statements on country living emphasized the positive aspects of country life: fewer temptations, safer environment for families, etc. In a frank

\footnotetext{
${ }^{1}$ Glaab and Brown, A History of Urban America, 53.
} 
testimony addressed to "Brother and Sister E.," she described their children as "unruly, passionate, and vicious." She further stated:

These parents should long ago have moved to the country; thus separating themselves and their children from the society of those whom they could not benefit, but would only harm. Steady industry upon a farm would have proved a blessing to these children. ${ }^{1}$

Ellen White wrote "An Appeal" 2 in 1882 to be read at a camp meeting.

According to the E. G. White Estate, this testimony "presents warnings and introduction which the writer, being absent in person, felt urged to give to the church." The three paragraphs of "An Appeal" for the first time (1) mention the unfriendly surroundings to religious life, (2) describe the current migration from country to city, (3) delineate the evil influences of city life, and (4) indicate Sodom's sin of pride, abundance, and idleness in the city.

The Pride and self-indulgence, the impiety and iniquity, by which we are surrounded have an influence upon us. . . . In choosing their surroundings, few make their spiritual prosperity the first consideration.

Parents flock with their families to the cities because they fancy it easier to obtain a livelihood there then in the country. The children having nothing to do when not in school, obtain a street education. From evil associates they acquire habits of vice and dissipation. The parents see all this; but it will require a sacrifice to correct their error, and they stay where they are until Satan gains full control of their children. Better sacrifice any and every worldly consideration than to imperil the precious souls committed to your care. . . .

Instead of the crowded city seek some retired situation where your children will be, so far as possible, shielded from temptation, and there train and educate them for usefulness. . . . All who would escape the

${ }^{1}$ Ellen G. White, Testimonies for the Church (Mountain View, CA: Pacific Press Publishing Assoc., 1946), 2:402-403.

${ }^{2}$ Ellen G. White, Testimonies for the Church, 5:217-235. 
doom of Sodom must shun the course that brought God's judgement upon that wicked city. ${ }^{1}$

This is the most extended statement which emphasizes parental responsibility for choosing a location for the education of their children.

From 1897, however, most of Ellen White's statements on country living are more decisive and eschatological. Her anti-urban sentiments burn with intensity. Notice this abrupt change in the following quotation written in 1897 :

The Lord gives warning to the inhabitants of the earth, as in the Chicago Fire and the Fires of Melbourne, London, and the city of New York. When God's restraining hand is removed, the destroyer begins his work. Then in our cities the greatest calamities will come.

Ere long there will be a sudden change in God's dealings. The Lord is preparing to visit the earth; for the iniquity of men is swelling to terrible proportions. ${ }^{2}$

Moving out of the cities was now an "imperative" for the preparation for the final crisis which Ellen G. White expected imminently. "Time has come," she wrote in 1903, "when, as God opens the way, families should move out of the cities. ${ }^{13}$ The calamities, conflicts, and God's impending judgment on the wicked cities are the major reasons in the subsequent statements on country living until the end. "There are reasons why we should not build in the cities. On these cities, God's judgements are soon to fall." 4 "The trade unions will be one of the agencies

${ }^{1}$ Ellen G. White, Testimonies for the Church, 5: 232-233.

${ }^{2}$ Ellen G. White, Manuscript 127, hereafter referred to MS, 1897, EGWRCAU.

${ }^{3}$ Ellen G. White, MS 50, 1903, EGWRC-AU.

${ }^{4}$ Ellen G. White, to Manager of Sanitarium and Food Factory, 1902, Letter 58, EGWRC-AU. 
that will bring upon the earth a time of trouble such as has not been since the world began." 1 "The time is near," she wrote in 1910 , "when large cities will be swept away, and all should be warned of these coming judgments."

In 1906 she made very clear the source of her message: "Out of the cities; out of the cities! This is the message the Lord has been giving me."

Brown and Glaab note, "American city dwellers were living on the rim of a social volcano." ${ }^{4}$ Ellen White also observed the dangers of city life which Brown and Glaab describe:

Violence in a dozen eastern cities accompanying with railroad strikes in the summer 1877, the shock of the Haymarket bomb in Chicago nine years later, the pitched battle strike and a small army hired by their employers at Homestead, Pennsylvania in 1892, and the destruction and carnage in Chicago stemming from the Pullman strike of 1894, all seemed to indicate that urban society was vulnerable. ${ }^{5}$

It seems, therefore, that sources of Ellen White's country-living message included her empirical observations of the city along with those of contemporary intellectuals as well as divine inspiration.

'Ellen G. White to George I. Bulter, 1903, Letter 200, EGWRC-AU.

${ }^{2}$ Ellen G. White, Evangelism (Washington DC: Review and Herald Pub. Assn., 1946), 29.

${ }^{3}$ Ellen G. White, Life Sketches of Ellen G. White (Mountain View, CA: Pacific Press Pub. Assn., 1943), 409.

${ }^{4}$ Glaab and Brown, A History of Urban America, 231.

${ }^{5}$ Ibid. 


\section{The Adventist Response in North America}

\section{G. I. Butler and W. W. Prescott}

As early as 1890 SDA leaders began to point out the advantages of country living. G. I. Butler, former president of the General Conference, wrote an article entitled "Rural Versus City Life" in the January 7 and 14, 1890, issues of the Review and Herald. ${ }^{1}$ A few years later W. W. Prescott, an SDA educator and administrator, wrote an article entitled "Country and City," warning SDAs to resist the trend of moving to the cities. He stated that because of the "corrupting influences of the cities," "we are removing our institutions from the cities to the country."2

\section{The Battle Creek Church}

Responding to Ellen White's counsel, "when the disciples followed their inclination to remain in large numbers in Jerusalem, persecution was permitted to come upon them, and they were scattered to all parts of the inhabited world"3 and "thus it has been in Battle Creek and in Oakland, ${ }^{14}$ a significant number of Adventist families moved out of Battle Creek. W. W. Prescott in a letter to Ellen White revealed that "between one and two hundred were preparing to leave as soon as

${ }^{1}$ G. I. Butler, "Rural Versus City Life," Review and Herald, January 7 and $14,1890,9-10,26-27$.

3.

${ }^{2}$ W. W. Prescott, "Country and City," Review and Herald, March 16, 1905,

${ }^{3}$ Ellen G. White, Testimonies for the Church, 8:215.

${ }^{4}$ Ellen G. White, Fundamentals of Christian Education (Nashville, TN: Southern Publishing Assoc., 1923), 495.

${ }^{5}$ Ellen G. White to John H. Kellogg, 1893, Letter 45, EGWRC-AU. 
possible." ${ }^{\text {A. }}$ T. Jones presented a sermon on October 14,1893 , "of an unusually interesting and solemn character," exhorting those not necessarily needing to remain in the 2,000-member Battle Creek Church to spread out into unentered areas "where they might be of more service to the cause. "2

\section{The Oakland Church}

After the San Francisco earthquake and fire in April 1906, another "moving out" occurred from Oakland. In a camp-meeting address given at Oakland in July 1906, Ellen White confirmed that an unknown number of Adventists had followed previous counsel and moved out of the area: "To the members of Oakland church I would say, Do not be discouraged because many of the brethren and sisters are going away in response to the counsels given that our people should leave the cities." She also appealed to the remaining listeners:

We are to give this city a decided warning, for God spared it in order that we may do a thorough and a quick work here. . . . Many will have to labor earnestly to help open the way. But until it is possible for them to leave, so long as they remain, they should be most active in doing missionary work, however limited their sphere of influence may be. ${ }^{3}$

${ }^{1}$ Ellen G. White, Country Living, 25.

${ }^{2}$ Alonzo T. Jones, Sermon on October 14, 1893, in the Battle Creek Tabernacle, Review and Herald, October 17, 1893, 660.

${ }^{3}$ Ellen G. White, "Behold, What Manner of Love," Review and Herald, September 27, 1906, 8-9. 
The World War II Era

After a period of little interest in country living in the early decades of the twentieth century, a revival in country living occurred. The SDA Encyclopedia states that the calamities of war, especially the bombing of Hiroshima and Nagasaki, caused "the General Conference to give serious consideration to setting up an organization promoting rural living for SDA's." ${ }^{1}$ In 1947, Lee E. Eusey also stated that the renewed emphasis was created by "the atomic incendiary bombing . . . with destruction of many cities through Europe and Japan . . . [which] stirred leadership to action." 2

\section{F. W. Wilcox}

As a long-time editor of the Review and Herald, F. W. Wilcox stated in a 1942 Review and Herald editorial: "The times in which we live are growing more and more serious. Complications of every character will develop. The effect of war, famine, and pestilence will be actively felt. ${ }^{13}$ However, Wilcox was quite reserved in believing that the members with heavy responsibilities in city churches or those who have no knowledge of farming should not attempt to leave the cities. He related

${ }^{1}$ The Seventh-day Adventist Encyclopedia, 1976 ed., s.v. "Rural Living."

${ }^{2}$ Lee E. Eusey, "The Solution of Social Problems through Rural Living as Accepted in Seventh-day Adventist Thinking" (Term paper, Michigan State College, 1947) Unpublished MS, EGWRC-AU, Document File 303-A. 23. 119: $2,11$.

${ }^{3}$ F. M. Wilcox, "Leaving the Cities," Review and Herald, August 27, 1942, 
an experience of some members who moved to the country without planning and therefore eventually met disaster.

\section{Carlyle B. Haynes}

Carlyle B. Haynes, director of the SDA War Service Commission, was considered as a chief campaigner for country living. He also assisted church members who had conflicts with labor union problems. He suggested a "better solution" to the problems, quoting Ellen White: "Educate our people to get out of the cities into the country where they can obtain a small piece of land, and make a home for themselves and their children." Believing that country living may not solve every problem, Haynes suggested that it was a "more adequate . . . more obedient solution than any adjustment made by agreement with labor unions."

In his articles in December 1947, Haynes quoted a recent report by L. H. Christian: "When World war II began one great city after another was bombed, and our people (most lived in cities) found themselves in great perplexity." Some tried to run away at night, but the farmers would not sell any food. "In one instance where some had ridiculed the divine instruction to leave the cities, fifty of our people perished in one dreadful bombing. ${ }^{2}$

${ }^{1}$ Carlyle B. Haynes, "Adventists and Labor Unions," Review and Herald, February 7, 1946, 18. 1947, 19.

${ }^{2}$ Carlyle B. Haynes, "Out of the Cities," Review and Herald, December 18, 
The Committee on Country Living

With renewed emphasis among SDAs on rural living shortly after World

War II, the trustees of the Ellen G. White Publications published a pamphlet in 1946 called "Country Living" which contained a compilation of the messages given by Ellen G. White from 1902 to 1906 , and written by her in numerous manuscripts. Haynes directed the committee ${ }^{1}$ and in April 1946 introduced the brochure to the readers of the Review:

In order that our believers may have these important messages in brief compass, they have been gathered from the many sources where they originally were written, and, by the trustees of the E. G. White publications, at the request of the General Conference and Committee, have been published in a ten-cent brochure entitled Country Living. This is available. ${ }^{2}$

Originally 5,000 copies were ordered, but within a few months the number was increased to 15,000 .

North American Commission for

Self-Supporting Missionary

Work

The General Conference began to give serious consideration to setting up an organization for promoting rural living for SDAs. In December 1945 it invited E. A. Sutherland, president of the Rural Education Association of Madison, Tennessee, to become secretary of a commission to be set up under the name of North American Commission of Self-Supporting Missionary Work, which began to function on July 1,

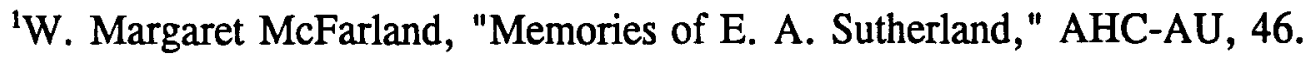

${ }^{2}$ Carlyle B, Haynes, "Out of the Cities," April 25, 1946, 6-7.
} 
1946. This commission was to "stand as a body of counselors to such individuals" as would "decide to locate their families in more rural communities and enter into some form of self-supporting missionary endeavor." ${ }^{11}$ McFarland remembers:

When Dr. Sutherland came to the General Conference in 1946, he immediately set about to work with Elder Haynes starting the commission of Rural Living. One of the things that was done was a compilation called Country Living, and another From City to Country Living, both from the White Estate. ${ }^{2}$

\section{SDA Commission on Rural Living (SDACRL) $^{3}$}

In August 1946, the General Conference recommended the merger of the North American Commission for Self-Supporting Missionary Work and the Committee on Country Living into the SDA Commission on Rural Living and appointed Sutherland as secretary and C. B. Haynes as assistant secretary. One of the major objectives of the commission was to

encourage our church members in cities to study the instruction about country living and to develop plans whereby they can fulfill this instruction; to provide counsel and information to those who are considering moving to the country; to hold regional institutes for selfsupporting missionary workers and individuals interested in country living. ${ }^{4}$

${ }^{1}$ General Conference of Seventh-day Adventists (Washington, DC), Minutes of Meetings of the General Conference Committee, December 9-15, 1945, Meeting of December 10, 1945.

${ }^{2}$ McFarland, "Memories of E. A. Sutherland," AHC-AU, 46.

${ }^{3}$ SDA Encyclopedia, 1976 ed., s.v. "Rural Living."

${ }^{4}$ General Conference Minutes of Seventh-day Adventists (Washington, DC), Minutes of Meetings of the General Conference Committee, August 19-25, 1946, Meeting of August 22, 1946. 
The Association of SDA Self-

Supporting Institutions

(ASI)

The General Conference at the 1945 Fall Council recommended the organization of an association of self-supporting institutions for a means of stimulating and encouraging this type of laymen's work, and bringing about a stronger tie between the self-supporting work and the regular organized work of the denomination. Another meeting was held on March 4 and 5 of 1947 in Cincinnati, Ohio, fostered by the Commission on Rural Living of which N. C. Wilson was the chairman and Dr. E. A. Sutherland was the secretary. Delegates from some twenty-five institutions, largely medical, formed the Association of SDA Self-Supporting Institutions and adopted a constitution and bylaws. The object of the association as set forth in the constitution was to foster and promote the interest of self-supporting missionary institutions operated by Seventh-day Adventists throughout the North American Division. Elder Wilson called the formation of this association "a great day in the history of the church." C. B. Haynes, assistant secretary of the Commission on Rural Living, spoke of the phenomenal response of Adventists to the recent publication Country Living. ${ }^{1}$

At a meeting at Grand Ledge, Michigan, September 3-5, 1951, it was decided that the Association of SDA Self-Supporting Institutions "foster the work hitherto carried on by the General Conference Commission of Self-Supporting

\footnotetext{
${ }^{1}$ Wayne McFarland, "Rural Living and Self-Supporting Work," The Ministry, July 1947, 31, 46.
} 
Missionary Enterprises." In 1957 an unpublished survey showed little Adventist interest in country living. ${ }^{1}$

In 1978 the General Conference Annual Council attendees reiterated the call and requested the republishing of the thirty-two-page booklet, Country Living: An Aid to Moral and Social Security.

\section{Educational Reform Movement Among $\underline{\text { Seventh-day Adventists }}^{2}$}

Seventh-day Adventist educational institutions have often been centers of influence for promoting the ethos and ideals of country living.

\section{Walla Walla College (1892- )}

Walla Walla College was opened in the pursuit of educational reform near Walla Walla, Washington, December 7, 1892. Edward A. Sutherland was asked to be the principal. ${ }^{3}$ Sutherland made Walla Walla College the first SDA college to serve its students a vegetarian diet, and at the first opportunity he purchased an additional eighty acres of land for gardens, orchards, and other crops. All of the teachers and students were to spend some time every day working together at productive manual labor, ${ }^{4}$ according to Ellen $\mathrm{G}$. White's philosophy of education:

${ }^{1}$ SDA Encyclopedia, 1976 ed., s.v. "Rural Living."

${ }^{2}$ See appendix 3 for self-supporting schools in current operation which are not described in this section.

${ }^{3}$ Gish and Christman, God's Beautiful Farm, 50-51.

${ }^{4}$ Ibid., 54-56. 
"Mental, intellectual, and physical culture should be combined in order to have welldeveloped, well-balanced men and women."1

\section{Avondale College (1895-)}

In Australia, the new Avondale School was taking shape under the direct supervision of Ellen White. Avondale School was begun in 1895, and by 1900 it was seen as a pattern for other SDA schools around the world.

Battle Creek College (1874-_)

For four years Sutherland struggled to remodel the Battle Creek College curriculum after the reform philosophy of education, as he learned it from Ellen White. ${ }^{2}$ He made the cafeteria vegetarian, abolished degrees, and worst of all, to some minds, plowed up the Battle Creek College athletic field and replaced it with a vegetable garden. ${ }^{3}$

Consequently, in 1901, Ellen White called on the General Conference to move Battle Creek College "away from the cities, on a large tract of land. ${ }^{14}$ The result was Emmanuel Missionary College in Berrien Springs, Michigan.

\footnotetext{
${ }^{1}$ White, Testimonies, 3:157, also 4:425.

${ }^{2}$ Gish and Christman, God's Beautiful Farm, 61.

${ }^{3}$ William C. Sandborn, "History of Madison College" (Ed.D. thesis, George Peabody College for Teachers, Nashville, 1953), 23.
}

${ }^{4}$ Arthur L. White, Ellen G. White: The Early Elmshaven Years: 1900-1905, vol. 5 (Washington, DC: Review and Herald, 1981), 92. 
Emmanuel Missionary College (1901-_)

On the 272-acre site of Emmanuel Missionary College, teachers and students worked together to erect the buildings. ${ }^{1}$ In 1902 Sutherland described his concept of a "correct" college campus:

We want our buildings to be simple and small, without heat and electricity, for that is the kind of buildings our students will find in the mission fields. There must be no large and handsome main building, nor must the buildings be erected on the quadrangular plan, but on a meandering line in order to get plenty of fresh air and sunshine. Furthermore such an arrangement will discourage the growth of pride and institutional spirit. $^{2}$

Madison School (1904-_)

In 1904 with their resignation from denominational employment, Sutherland and Magan united their philosophy of educational reform with the methodology of self-support, and the offspring of that union was the beginning of the self-supporting movement in SDA education. Sutherland and Magan went into the South and built the Nashville Agricultural and Normal Institute, ${ }^{3}$ which included the "Madison School, "4 later renamed Madison College in $1937 .^{5}$

${ }^{1}$ Emmett K. VandeVere, The Wisdom Seekers (Nashville, TN: Southern Publishing Assn., 1972), 23.

${ }^{2}$ Ibid., 106-107.

${ }^{3}$ SDA Encyclopedia, 1976 ed., s.v. "Madison Institute."

${ }^{4}$ Gish and Christman, God's Beautiful Farm, 102.

${ }^{5}$ SDA Encyclopedia, 1976 ed., s.v. "Madison Institute." 
The Wildwood Sanitarium and Medical Missionary

Institute (1904-_)

The widely known Wildwood Sanitarium and Medical Missionary Institute was founded in 1941 on a 500-acre tract at Wildwood, Georgia, about ten miles south . of Chattanooga, Tennessee. ${ }^{1}$ The chief founder was Willmont D. Frazee, ${ }^{2}$ in partnership with Neil Martin of Alabama and George McClure from Chunky, Mississippi. ${ }^{3}$

Wildwood "outposts"

In 1950 a little junior academy was started on Lookout Mountain, Tennessee, then moved in 1958 to the Sequatchie Valley near Dunlap, Tennessee, to become known as Stonecave Institute. ${ }^{4}$

The second "outpost" growing out of Wildwood was Eden Valley Institute, near Loveland, Colorado, in 1962. Since then the growing list of Wildwood's "children" includes Beautiful Valley (West Virginia, 1966), Castle Valley (Utah, 1970), Uchee Pines (Alabama, originally Yuchi Pines, 1970), Refugio Las Palmas (La

"Wildwood Historical Sketch" (Wildwood, GA: Wildwood Sanitarium, 1974), 4: EGWRC-AU, Document File 357-d.

${ }^{2}$ A. L. White to Gordon Geer, November 5, 1959, Q\&A File 31-c-28, EGWRC-AU.

${ }^{3}$ W. D. Frazee, "Wildwood Story," Friday Evening Vesper Service, December 28, 1956. Included as Appendix I of Alexander Currie, "Observations and a Personal Evaluation of the Wildwood Concept of Self-Supporting Ministry," Term Paper, Andrews University, 1976, p. 55, EGWRC-AU Document File 357-d.

4"Wildwood Historical Sketch," 4; Pierson, Miracles, 71. 
Ceiba, Honduras, 1971), Catskill Missionary Outpost (New York State, 1972), Shawnee Hills (Illinois, 1972), Riverside Farm Institute (Zambia, 1973), Silver Hills (British Columbia, 1973), Meadowbrook (Missouri, 1973), Woodland Park (South River, Ontario, 1974), ${ }^{1}$ Mountain Missionary Institute (New Hampshire, 1974), ${ }^{2}$ AChee-Ne Missionary Training School (Korea, 1975$),{ }^{3}$ Mt. Akagi Sanitarium (Japan, $1951 / 1978),{ }^{4}$ and others.

Wildwood has become the largest of the SDA self-supporting organizations, overseeing "more than a dozen Institutions along with many smaller ventures of faith." ${ }^{5}$ It has continued to burgeon into the 1990s. ${ }^{6}$

Weimar Institute (1919-_)

A group of SDA leaders, including Dr. Raymond Moore and the board of the Hewitt Research Center, then in Berrien Springs, Michigan, was probing the possibility of opening a college that could begin anew in pursuing the SDA medical and educational philosophy as they understood it. Some seventy interested individuals

"Wildwood Historical Sketch", 5-14.

2Pierson, Miracles, 114.

${ }^{3}$ Ibid., 153.

${ }^{4}$ Ibid., 156-157.

${ }^{5}$ Currie, "Observations and a Personal Evaluation of the Wildwood Concept of Self-Supporting Ministry." Term paper, Andrews University, 1976, Document File 357d, Ellen G. White Research Center. Andrews University, Berrien Springs, MI. 2.

${ }^{6}$ As of 1993, Outpost Centers Incorporated has 78 member outposts in 21 States and 30 foreign countries. 
met in Carmichael, California, on April 21, 1977, to consider the purchase of the former Weimar Medical Center as the campus for a new self-supporting college. They voted to purchase the property for $\$ 1,150,000 .^{1}$ Now including Weimar College, Weimar Academy, and the NewStart health conditioning center, Weimar Institute was at the cutting edge of medical and educational reform in the $1990 \mathrm{~s}$. Weimar has also given rise to other schools more or less after the same pattern. Two of these are Hartland Institute in Virginia, and Black Hills Missionary College in South Dakota.

\section{Korean Adventist Country-Living Movement}

The brief history of Korean Adventist country-living movement is discussed in order to understand the country-living impulse ${ }^{2}$ of Korean Adventists, and if possible, to solve the problems pertaining to their country-living movement.

\section{Refugee Living in the Mountains} (1944-45)

Following the invasion of Japan, Korean Adventists were severely persecuted and put in prisons. After Elder Tae Hyun Choi, the president of the Korean Union Mission, died a martyr in prison, the church was disbanded on December 17, 1943. Many "heroes of faith"3 such as Myung Kil Kim, Nae Hyun

${ }^{1}$ Pierson, Miracles, 125-127.

${ }^{2}$ George Knight uses the term in Early Adventist Educators (Berrien Springs, MI: Andrews University Press, 1983), 3, 5.

${ }^{3}$ Young Lin Lee, Korean Adventist History (Seoul, Korea: Sun Kwang Moon Hwa Sa, 1968), 82. 
200 miles northwest of Gapyung, Kyunki Do, for their faith. ${ }^{1}$ Because of the Japanese persecution, Kyung Cheol Cho, a deacon, sold all of his property and moved to Hasong Kwan, Kangwondo, from his hometown, Sundol, Pyunghanbook Do, for his faith. He often visited the scattered believers' houses in disguise as a peddler. ${ }^{2}$ After the August 15 Liberation in 1945, these faithful members came out of the mountains and restored the church organization.

Influence of James Lee, Hyunchul Shin, and Pyungan Kim (1980- $)$

From the early 1980s, the influence of James Lee, Hyunchul Shin, and Pyungan Kim was another force behind the Korean Adventist country-living movement. James Lee, born in Korea as a son of missionaries, worked in Korea as a missionary for fourteen years from 1946-1960 still making trips to Korea.

He introduced outpost evangelism as a blueprint for modern evangelism, and joined the self-supporting independent ministries.

Two faculty members of Korean Union College, Hyunchul Shin and Pyungan Kim, promoted country living, but Pyungan Kim emphasized natural remedies also. Hundrews of believers have followed their ideology.

${ }^{1}$ Ibid., 81.

${ }^{2}$ Man Kyoo Oh, Adventist History (Seoul, Korea: Sung Kwang Moon Hwa Sa, 1968), 336. 
Mountain-living Group (1959-70)

A few Adventist believers studied such passages as "As were the days of Noah, so will be the coming of the Son of Man" (Matt 24:27); "Do you not say, 'There are yet four months, then comes the harvest'?" (John 4:35); and "For two thousand and three hundred evenings and mornings: then the sanctuary shall be restored to its rightful state" (Dan 8:14). They applied 120 years of Noah's warning to the warning work of the three angels' messages since 1844 when the period of 2300 years ended. ${ }^{1}$ By adding 120 years to the year 1844 , they concluded that Jesus Christ would come in 1964. This interpretation caused agitation and a sensation among the Korean Adventists, and many families began to return to the mountains in 1959. About sixty families lived in Bakdaljae ${ }^{2}$ and Donghwawon of Moonkyung Sejae ${ }^{3}$ during $1960-1963,{ }^{4}$ and many other family groups resided at Jiri Mountains; in addition several single families were scattered in the mountains. ${ }^{5}$

Other reasons for the mountain-living movement were the influence of the country-living movement from North America and the translation of the booklet

${ }^{1}$ According to Ezek 4:6 and Num 14:34 a day is one year in prophetic interpretation. See William H. Shea, Selected Studies on Prophetic Interpretation, Daniel and Revelation Committee Series, vol. 1 (Washington, DC: Review and Herald Publishing Assn., 1982), 72-75.

${ }^{2}$ Located at Kumjung Myun, Bonghwagoon, Kyung Gook, Southeast Korea.

${ }^{3}$ Located at Dongwawon, Mookyunggoon, Kyung Book, Southeast Korea.

${ }^{4}$ Yoo Bok Kim, "A General Survey of the Country Living in the Writings of Ellen White and Its Korean Application" (M.A. thesis, Seoul, Korea: Samyook University Press, 1991), 38-40.

${ }^{5}$ Ibid. 
Country Living by the students of the department of theology at Korean Union College (now Samyook University) in the beginning of the 1960s.

Their repeated time-setting and their conflicts with the local churches brought significant problems to the Korean churches. Many people abandoned the faith, while some members left the church. ${ }^{1}$

Tae Bong Kang, Chang Soon Chung, and Hae Shim Chun, rigidly doctrinaire, held "illegitimate meetings" at Dosari, Ichun, Kyungki Do (April 18-22, 1968) and at Gongdo, Ansung Goon, Kyungki Do, from May 31 through June 3, 1968 , to again set prophetic times. ${ }^{2}$

\section{Country Living (1970s)}

Korean Adventists saw a new era for country living as Han Tae Joo, ${ }^{3}$ Han Pyung Joo, ${ }^{4}$ and Kyo Young Lee were successful in greenhouse farming and vegetable and mushroom raising. ${ }^{5}$

Another new direction in country living was seen by Eu Kon Kim. After graduating from the medical missionary program at Wildwood Institute in Georgia, he came back to Korea and opened "Achine Self-Supporting Mission Institute." At the

\section{${ }^{1}$ Ibid.}

${ }^{2}$ Ibid.; see also Sang Do Kim, "Reflection in the Meeting at Dosari," Church Compass, June 6, 1968.

${ }^{3}$ Yoo Bok Kim, "A General Survey of the Country Living in the Ellen White Writings and Its Korean Application," 41.

${ }^{4}$ Ibid.

${ }^{5}$ Ibid., 42. 
beginning, about twenty people joined the Institute; after three years about thirty people gathered there. ${ }^{1}$

They also started Dong Sung Samyook Middle School at Kwang Am Ri, Suboomyun, Kwangjoo Goon, Kyungki Do, as a self-supporting educational reform movement.

The third aspect of country living in this era was the SDA Reform Movement which has penetrated into the faith of many Korean Adventists through the influence of a former SDA pastor. Many believers began to leave the local churches for the country, while criticizing the SDA denomination. ${ }^{2}$

\section{Cultist, Myung Ho Park (1980- )}

While there are still the extreme groups of "time-setters" as well as followers of the SDA Reform Movement, the majority of those who moved to the country are supporting the local churches through evangelism and by starting new churches in cooperation with the established churches. ${ }^{3}$

The most disturbing movement in the 1980s in the history of Korean Adventists occurred when many believers began to leave the established churches in

\section{${ }^{1}$ Ibid.}

${ }^{2}$ Ibid.

${ }^{3}$ Ibid., 44-45. 
favor of living in the mountains under the influence of Myung Ho Park. ${ }^{1}$ Park teaches that God is the God of the valleys and mountains, and that in order to live with God, man must live in the mountains. In fact, he seems to be a pantheistic fanatic. Myung Ho Park mixed the Bible with the superstitious book Jung Gam $\underline{\text { Rok }}^{2}$, and teaches many mystic theories. In Korea, he has about three thousand followers and about five hundred in North America. These followers are distributing tapes and videos of Myung Ho Park's sermons to Korean Adventists in North America.

There are many successful families in country living who farm for their sustenance in the country and are supporting local churches. But many individuals have problems in understanding and applying the messages of country living.

${ }^{1}$ Ibid., 46. His original name was Kwang Kyu Park, born in Daechun, Choong Nam. Since the 1960s, he has lived in Magundam, Chiri Mountain. He became a cult leader of Noah's Ark (later changed to Elijah Mission Institute, located at 171-1, Dun Dun 2 Ri, Socho Myun, Wonsung Gun, Kangwon Do in the 1980s).

2Jung Gam Rok was written by Nam Sa Go during the reign of King Myungjong of the Lee Dynasty in Korea about four hundred eighty years ago (ca. 1510). This book prophesied about major events that would occur every year in the future. The most important prophecy was that a god would come in the person of Chung Do Ryung, and also predicted the time, place, and family of Chung Do Ryung's birth. As the Lee Dynasty had continued to rule over Korea for five hundred years in Seoul, Chung Do Ryung would rule five hundred years in Kae Ryong Mountain, located near Daejun, Choong Chungnam Do, Korea. Even though this prophecy was not fulfilled, some people still have believed, on the basis of this prophecy, that Jesus would come the second time. By this prophecy many cultists have asserted that they are Jesus. Myung Ho Park applies this prophecy to himself, and he is fulfilling the major events foretold in the book until the end of time. Myung Ho Park sends his messengers to over one hundred countries. 
Korean Adventists generally accepted these messages [counsels on country living by Ellen G. White] in the eschatological way of faith and applied them to the life remote from any town or church. The effect of the wrong applications of them produced many problems in the church revival and increase of Christian faith, and church member control. ${ }^{1}$

'Yoo Bok Kim, "A General Survey", 72. 
CHAPTER III

\section{COUNTRY LIVING AND CITY LIVING IN THE WRITINGS OF ELLEN G. WHITE AND OTHER ADVENTISTS}

This chapter describes and explains Ellen G. White's thoughts and those of her associates and other SDAs on country living in comparison to city living. When she says "Take your families away from the cities, is my message, ${ }^{11}$ what is meant by cities or country? People have different opinions on the meaning of city or country as mentioned by Ellen G. White. Even though this project report does not attempt a systematic consideration of economic or agronomic issues involved in country living, some suggestions of Adventists other than Ellen G. White are presented concerning occupations in rural locations. Finally some guidelines are given for the location of residences and institutions.

\section{God's Original Plan: Country}

Ellen G. White stresses country living as God's original plan referring to the Garden of Eden as our first parents' home. "In the beginning He placed our first

${ }^{1}$ Ellen G. White to Brethren, 1902, Letter 182, EGWRC-AU. 
parents amidst the beautiful sights and sounds He desires us to rejoice in today."1

Her inspiration points out the words of Moses to the tribes of Israel:

Among the blessings of the lot of Ephraim and Manasseh, Moses enumerated "the chief things of the ancient mountains, and the precious things of the lasting hills." In his last prophetic words to the tribes of Israel, he dwelt with peculiar earnestness upon the precious things of the hills. While the chosen people were wandering in the desert, he encouraged them by describing their promised inheritance as a land of hills and valleys. ${ }^{2}$

Her major concern is for total health. "The more nearly we come into harmony with God's original plan, the more favorable will be our position to secure health of body and mind, and soul. ${ }^{13}$

\section{Physical Surroundings of}

Country

In the counsels of Ellen G. White, country is described as being surrounded by "the quiet of dawn or twilight in the green valley," "some farming district, surrounded with green fields, the woods and hills and brooks, the clear skies and the fresh, pure air"s and "pure sights and sounds . . . and the sense of God's presence pervading all nature, 'tending' to uplift the mind, to soften the heart, and

${ }^{1}$ Ellen G. White, The Ministry of Healing (Mountain View, CA: Pacific Press Publishing Assn., 1942), 365.

${ }^{2}$ Ellen G. White, "Among the Mountains," The Signs of the Times, February $2,1882,1: 282$.

${ }^{3}$ Ellen G. White, The Ministry of Healing, 365.

${ }^{4}$ Ellen G. White, Country Living, 15.

${ }^{5}$ Ellen G. White, The Ministry of Healing, 191. 
strengthen the will to resist temptation."1 She expresses her own experience as "a little taste of Eden":

I look at these flowers, and every time I see them, I think of Eden. They are an expression of God's love for us. Thus He gives us in this world a little taste of Eden. He wants us to delight in the beautiful things of His creation, and to see in them an expression of what $\mathrm{He}$ will do for us. He wants us to live where we can have elbow room. ${ }^{2}$

For Ellen G. White, country is understood not necessarily as deep mountains; rather she emphasizes natural environment for our dwelling, and some farm land to cultivate. The writings of the Spirit of Prophecy do not counsel that every Seventh-day Adventist should become a farmer, but those writings do urge that each family should possess a piece of land large enough to produce the family food supplies. $^{3}$

Many are unwilling to earn their bread by the sweat of their brow, and they refuse to till the soil. But the earth has blessings hidden in her depths for those who have courage and will and perseverance to gather her treasures. Father and mothers who possess a piece of land and a comfortable home are kings and queens. ${ }^{4}$

${ }^{1}$ Ellen G. White, MS 12, 1900, EGWRC-AU, 2.

${ }^{2}$ Ellen G. White, MS Release 927, Document File 303a, EGWRC-AU.

${ }^{3}$ Ellen G. White, Testimonies for the Church, 6:178-179; Ellen G. White to Hall, Feb 5, 1904, Letter 63, EGWRC-AU.

${ }^{4}$ Ellen G. White, Fundamentals of Christian Education, 326-327. 
Country Heritage of Noble

People in the Bible

Ellen White found in the Bible many examples of godly individuals who were especially directed by God to live in the country.

Adam and Eve

The home of our first parents was to be a pattern for other homes as their children went forth to occupy the earth. God placed Adam and Eve in a garden where they were given useful occupation as "a blessing, to strengthen their bodies, expand their minds and develop their character."1

Isaac and Joseph

Isaac and Joseph grew up in the country and became overcomers against fatal temptations. Isaac's real character is revealed in his faithful obedience to his father on Mount Moriah (Gen 22:5-10). Joseph's true character is seen many times, especially in the dungeon (Gen 39,40$).^{2}$

Elijah

One of the most powerful people in the Bible was "Elijah the Tishbite, who was of the settlers of Gilead (1 Kgs 17:1). The place where Elijah grew up was a

${ }^{1}$ Ellen G. White, Education, 21-21.

${ }^{2}$ Ellen G. White, Patriachs and Prophets (Mountain View, CA: Pacific Publishing Assn., 1958), 209, 213, 222, 332. 
wilderness territory that had an influence in developing the rugged traits found in his character, and building his faith and spiritual relationship with God. ${ }^{1}$

John the Baptist

"And the child continued to grow . . . and he lived in the deserts until the day of his public appearance to Israel" (Luke 1:80). John refrained from seeking honor for himself, but directed all his followers to Jesus. It was his unselfish joy in the ministry of Christ that presented the highest type of nobility ever revealed in man. ${ }^{2}$ The following quotation explains where John was schooled for his life work, and also to a large degree where his character developed.

It was John's choice to forego the enjoyments and luxuries of city life for the stern discipline of the wilderness. Here his surroundings were favorable to habits of simplicity and self-denial. Uninterrupted by the clamor of the world, he could here study the lesson of nature, of revelation and of providence. ${ }^{3}$

Jesus

In choosing an earthly home for His Son, God has shown the principles for choosing a location for a home. No other person on this earth will ever be called to accomplish a work greater than that of Jesus. What type of place did the Father choose for the childhood of Jesus?

${ }^{1}$ Ellen G. White, Prophets and Kings (Mountain View, CA: Pacific Press Publishing Assn., 1943), 119-120.

${ }^{2}$ Ellen G. White, The Desire of Ages (Mountain View, CA: Pacific Press Publishing Assn., 1940), 219.

${ }^{3}$ Ellen G. White, Testimonies for the Church, 8:221. 
He came as God's Ambassador, to show us how to live so as to secure life's best results. What were the conditions chosen by the infinite Father for His Son? A secure home in the Galilean hills; . . . the quiet of dawn or twilight in the green valley; the holy ministries of nature; His study of creation and Providence. ${ }^{1}$

Even though Jesus had to grow up in the town of Nazareth to be an example to others, He often went into the hills and among nature. There He prepared for His mission in this life.

So with the great majority of the best and noblest men of all ages. Read the history of Abraham, Jacob, and Joseph; Moses, David, and Elisha. Study the lives of men of later times who have most worthily filled positions of trust and responsibility, the men whose influence have been most effective for the world's uplifting. ${ }^{2}$

\section{Question of Distance from City for Both Home and Institutional Location}

When country/rural is mentioned for residential and institutional locations,

Ellen G. White does not mean absolutely isolated areas. When she says she was getting settled in her new rural home, it was "four miles from the city."

I shall never, never settle in or close to a city, if it is possible for me to be elsewhere, and I do not mean to advise you to do so. Keep out of the cities. I shall always be glad to be as many miles as possible away from the smoke and clamor of the city. ${ }^{4}$

${ }^{1}$ Ellen G. White, The Desire of Ages, 365-366.

${ }^{2}$ Ellen G. White, The Ministry of Healing, 366.

${ }^{3}$ Arthur L. White, Ellen G. White: The Progressive Years: 1862-1876, vol. 2 (Washington, DC: Review and Herald Publishing Assn., 1985), 412.

${ }^{4}$ Ellen G. White, 1900, Letter 57, EGWRC-AU. 
To some people, country living means a complete isolation from

civilization. To Ellen G. White, it meant a rural setting away from the crowded, congested parts of a city. At the time she wrote, "Mountain View was a country location," forty miles south of San Francisco, twelve miles north of San Jose. ${ }^{1}$

In 1904 she looked upon Glendale as a country location. It was a village twenty miles north of Los Angeles. About the same time, she looked upon Takoma Park as country location seven miles from the capital building. ${ }^{2}$

Another specific instance to indicate that to Ellen G. White a country location did not mean a matter of distance, but natural environment, is shown when she emphasized accessibility of our institutions.

When brethren Sutherland and Magan were planning to establish a selfsupporting school in the South and intended to go up into the highland, perhaps a couple of hundred miles from Nashville, Ellen White said no, we must be closer to people, and she was instrumental in leading them to the purchase of the property of Madison, twenty miles north of Nashville. $^{3}$

Ellen White, while calling for schools in the country, at the same time pointed out that as long as we have church members with families living in the cities we must provide church schools for them.

\footnotetext{
${ }^{1}$ Arthur L. White to J. W. Bothe, Document File 303a, EGWRC-AU.

${ }^{2}$ Ibid.

${ }^{3}$ Ibid.
} 
Much more can be done to save and educate the children of those who at present can not get away from the cities. This is a matter worthy of our best efforts. Church schools are to be established for the children in the cities. $^{1}$

\section{Certain Guiding Principles in Choosing a \\ Location for an Institution}

\section{Close Proximity to a Densely}

\section{Populated District}

Whereas our institutions are not to be located in the congested cities, they

are not to be set up in isolated places. Ellen White described the proximity of Loma

Linda to certain small cities and the particular advantage she saw in its location:

In the fall of 1903 I had a vision of a sanitarium in the midst of beautiful grounds, somewhere in Southern California, and no property I had visited answered to the presentation given in this vision. ... While attending the General Conference of 1905, at Washington, D. C., I received a letter from Elder J. A. Burden, describing a property he had found four miles west of Redlands, five and one half miles southeast of San Bernardino, and eight miles northeast of Riverside. As I read this letter, I was impressed that this was one of the places I had seen in vision. But more important than magnificent scenery and beautiful buildings and spacious grounds is the close proximity of this institution to a densely populated district. $^{2}$

'Ellen G. White, Child Guidance (Washington, DC; Review and Herald Publishing Assn., 1954); 306; quoted in Arthur L. White to J. W. Bothe.

${ }^{2}$ Ellen G. White, Life Sketches of Ellen G. White, 405-406; quoted in White and Sutherland, From City to Country Living, 19. 
Natural Environment and Utilities

When it was necessary to move the Pacific Press from Oakland, California, to a less crowded location, a site was found in the town of Mountain View. Ellen White described the benefits of the location:

Mountain View is a town which has many advantages. It is surrounded by beautiful orchards. The climate is mild, and fruit and vegetables of all kinds can be grown. The town is not large, yet it has electric light, mail carriers, and many other advantages usually seen only in cities. ${ }^{1}$

It is clear that the rural locations of institutions should be within easy access of the centers of population and yet be sufficiently isolated to gain the benefits of the rural setting. These approving counsels, describing the country locations ideal for institutions, provide guidance regarding what is meant by country living. ${ }^{2}$

\section{Some Guiding Principles in Choosing a Location for a Home}

$\underline{\text { Religious and Moral Influence }}$

In choosing a home, God would have us consider first of all the moral and religious influences that will surround our families. ${ }^{3}$

${ }^{1}$ Ellen G. White, to Edson and Emma 1904, Letter 141, EGWRC-AU; quoted in White and Sutherland, From City to Country Living, 18.

${ }^{2}$ See Ellen G. White, Testimonies for the Church 7:80-89; Ellen G. White, Medical Ministry (Mountain View, CA: Pacific Press Publishing Assoc., 1963), 308-309; Ellen G. White, Evangelism, 76-78.

${ }^{3}$ Ellen G. White, Patriarchs and Prophets 169. 
We should choose the society most favorable to our spiritual advancement. ... We should not voluntarily expose ourselves to influences that are unfavorable to the formation of Christian character. ${ }^{1}$

\section{A Rural Environment with Land for Cultivation}

Undoubtedly a rural environment furnishes the most favorable conditions for rearing a family. Instead of living where only the works of men can be seen, "go where you can look upon the works of God. Find rest of spirit in the beauty and quietude and peace of nature. Let the eye rest on the green fields, the groves, and the hills."

How much better it is for active boys to employ some of their spare time gardening, caring for the animals, cutting wood, repairing fences, making furniture, doing the plumbing, and so forth, rather than for them to find their recreations on the street.

Parents can secure small homes in the country, with land for cultivation where they can have orchards and where they can raise vegetables and small fruits. . . . God will help His people to find such homes outside of the cities. ${ }^{3}$

He [God] desires us to surround our homes with beauty of natural things. . . . Nearly all dwellers in the country, however poor, could have about their homes a bit of grassy lawn, a few shade trees, flowering shrubbery, or fragrant blossoms. They will bring into the home life a softening, refining influence, strengthening the love of nature, and

${ }^{1}$ Ellen G. White, The Adventist Home (Hagerstown, MD: Review and Herald Publishing Assn., 1980), 131.

${ }^{2}$ Ellen G. White, Ministry of Healing, 367.

${ }^{3}$ Ellen G. White, Medical Ministry, 367. 
drawing the members of the household near to one another and near to God. ${ }^{1}$

\section{No Fixed Rule for Everybody}

Some factors such as family background, ages of children if any, educational needs, occupational skills, and missionary spirit need to be considered in determining "the case of each family as to just what constitutes country and the degree of isolation desirable. ${ }^{2}$ "There will be laymen who will move into towns and cities and into apparently out-of-the-way places that they may let the light . . shine forth to others. ${ }^{3}$ Whether residence is chosen in a village or town, in a sheltered place not far from a metropolitan area, the situation of our homes should be "out of the cities," "into the country, where" we "can obtain a small piece of land"4 where "the houses are not small, and crowded closely together."

What to Watch for in Selecting

a Home Location

Location in relation to work should be located within relatively easy and convenient access to the place of labor of the wage earner. In regard to the adaptability of the property, such service as electricity and telephone, and a good

${ }^{1}$ Ellen G. White, The Ministry of Healing, 370.

${ }^{2}$ White and Sutherland, From City to Country Living, 19-20.

${ }^{3}$ Ellen G. White, "Missionary Work," Review and Herald, September 29, 1891, 2:521; idem, Testimonies for the Church, 2:115.

${ }^{4}$ Ellen G. White, Country Living, 10.

${ }^{5}$ White and Sutherland, From City to Country Living, 17. 
water supply, trees, and some pasture land and tillable land for garden, vineyard, and orchard should be considered. The success of country living will be largely dependent upon the accessibility to a church, church school, and SDA neighbors. As to the size of land, a half acre will provide room for a home and a good garden. An acre will furnish ample room for a home, a garden, and for animal husbandry carried on a small scale. Two or three acres would be more desirable if pasture land is desired. For a vegetarian family one acre is sufficient to provide the necessary food. ${ }^{3}$

\section{Occupations in Rural Locations}

It would seem quite natural that country living should include some form of agricultural activity, at least on a part-time basis. Regardless of the extent to which the family may wish to engage in gardening, no country living would be complete without the raising of some flowers, vegetables, and small fruits. ${ }^{4}$

\section{The Most Favorable Occupation}

"In God's plan for Israel, every family had a home on the land, with sufficient ground for tilling. . . . And no devising of men has ever improved upon that plan." 5

\footnotetext{
${ }^{3}$ The 9 important factors presented in White and Sutherland, From City to Country Living, 33-36. The 4 factors are selected out of the 9 factors.

${ }^{4}$ White and Sutherland, From City to Country Living, 37.

${ }^{5}$ Ellen G. White, Counsels to Parents, Teachers, and Students (Mountain View, CA: Pacific Press Publishing Assn., 1943), 275-276.
} 
By the distribution of the land among the people, God provided for them, as for dwellers in Eden, the occupation most favorable to development-the care of plants and animals. ${ }^{1}$ The men who held fast God's principles of life dwelt among the fields and hills. They were tillers of the soil, and keepers of flocks and herds; and in this free, independent life, with its opportunities for labor and study and meditation, they learned of God, and taught their children of His works and ways. ${ }^{2}$

Such employment was not given because of sin. The great Master Himself blessed the work of tilling the soil. ${ }^{3}$ In the choice of location, the family sustenance is of first importance. Only those who are fully prepared through proper training and background should attempt to farm for a living.

\section{The Rural Home for the City}

Worker $^{4}$

Many people might enjoy the advantages of a rural environment and still maintain their employment in the city. In this way the family could maintain their income status. Everybody cannot work on the farm, depending entirely upon the soil as a means of livelihood, due to his/her physical condition and agricultural background.

${ }^{1}$ Ellen G. White, Education, 43.

${ }^{2}$ Ibid., 33-34.

${ }^{3}$ Ellen G. White, Selected Messages (Washington, DC: Review and Herald Publishing Assn., 1958), 2:355.

${ }^{4}$ This is suggested in White and Sutherland, From City to Country Living, 31. 
Owning a Business in the Country

Some people who are employed in the city may be able to establish their own business in a rural area. They can also hire the people who are moving to the country. The self-operated business is more likely free from government regulation and labor problems. ${ }^{1}$

Believers who are now living in the cities will have to move to the country, that they may save their children from ruin. Attention must be given to the establishment of industries in which those families can find employment. . . . Pray over the matter, and remember that God stands at the helm, that $\mathrm{He}$ is guiding the work of the various enterprises. ${ }^{2}$

Ellen White says, "This is a positive necessity in this country," "that families that can not obtain work in the cities because of observance of the Sabbath may buy small farms and make their own living. ${ }^{3}$

Conditions in the City: Reasons for Leaving the Cities

The writings of Ellen G. White on the subject of country living reveal a strong appeal and warning for parents to leave the cities. What is it about city life that makes it an undesirable location to raise children? What is it about the conditions of the city that caused Ellen G. White to plead with parents to move to the country?

${ }^{1}$ Ibid., 32.

${ }^{2}$ Ellen. G. White to "Those in Positions of Responsibility in the Southern Field:" 1902, Letter 25, EGWRC-AU; quoted in Ellen G. White, Country Living, 19-20.

${ }^{3}$ Ellen G. White, Welfare Ministry (Washington, DC: Review and Herald Publishing Assn., 1847), 184. 
Religious and moral conditions

One of the major conditions of the cities is the evil influence, unfriendly to religious life. "From evil associates, they acquire habits of vice and dissipation. . . . Satan gains full control of their children. . . . They will be assailed by temptations." 1

God's people do not fit into the "corrupting influences of city life,"2 and unless God's people move out of the cities into the country, "many of the youth, and many also of those old in years, will be ensnared and taken by the enemy. ${ }^{13}$ The young minds of children can be easily influenced, and they are usually the first ones to follow a new fad. The advertising of today is aimed at the innocence of youth. The dollar is king in the minds of many adults and they do not care if youth are corrupted because of their products and influences.

Life in the cities is false and artificial. The intense passion for money getting, the whirl of excitement and pleasure seeking, the thirst for display, the luxury and extravagance, all are forces that with the great masses of mankind, are turning the mind from life's true purpose. They are opening the door to a thousand evils. Upon the youth they have almost irresistible power. ${ }^{4}$

${ }^{1}$ Ellen G. White, Testimonies for the Church, 5: 232-233.

${ }^{2}$ Ellen G. White, MS 133, 1902, EGWRC-AU.

${ }^{3}$ Ellen G. White, Testimonies for the Church, 8:101.

${ }^{4}$ Ellen G. White, The Ministry of Healing, 364. 
It is no wonder that strong words are used for a warning to leave the cities. "The world over, cities are becoming hotbeds of vice. On every hand are the sights and sounds of evil, and enticements to sensuality and dissipation."1

Physical surroundings

"It was not God's purpose that people should be crowded into cities, huddled together in terraces and tenements. "2

The physical surroundings in the cities are often a peril to health. The constant liability to contact with disease, the prevalence of foul air, impure food, the crowded, dark, unhealthful dwellings, are some of the many evils to be met. $^{3}$

There is no doubt that city surroundings are not desirable to the health of body and mind. There is not one family in a hundred who will be improved physically, mentally, or spiritually by residing in the city. ${ }^{4}$

Strikes, turmoil, confusion, crimes

Life in the large cities is becoming highly entangled. Every individual in the city becomes dependent upon many other individuals. Any accident in normal functions of service may bring inconvenience and a total halt in the whole mechanism. In addition, organizations like labor unions have a strong controlling power that may

${ }^{1}$ Ibid., 363.

${ }^{2}$ Ibid., 365 .

${ }^{3}$ Ibid., 305; Ellen G. White, The Adventist Home, 135.

${ }^{4}$ Ellen G. White, MS 76, 1905, EGWRC-AU. 
coerce others to join in activities that are contrary to the basic principles of Christianity. ${ }^{1}$

The trade union and confederacies of the world are a snare. Keep out of them; and away from them, brethren. . . . The turmoil and confusion that fill these cities, the conditions brought about by the labor unions and the strikes, would prove a great hindrance to our work. ${ }^{2}$

The cities will become worse and worse, for there will be strife and bloodshed, ${ }^{3}$ and "the tide of corruption and crime is continually swelling. Every day brings the record of violence, robberies, murders, suicides, and crimes unnameable. ${ }^{44}$

Amusement and entertainment centers

Children are by nature very active; if nothing constructive is provided for them to do, they will find other types of amusement or entertainment. If the parents are too busy or do not want to take the time to train their children, the enemy will surely be glad to train them. The children in the cities are surrounded with allurements calculated to tempt the appetite. ${ }^{5}$ There is not much work for children in the cities. They do not have many good recreations, so they have a lot of idle time to

'Ellen G. White, Country Living, 6, 9-12.

${ }^{2}$ Ibid., 10-11.

${ }^{3}$ Ellen G. White, MS 76, 1905, EGWRC-AU.

${ }^{4}$ Ellen G. White, The Ministry of Healing, 363.

${ }^{5}$ Ellen G. White, Temperance (Mountain View, CA: Pacific Press Publishing Assn., 1949), 101. 
pursue wrong amusements that harm their moral, and physical life. Some of these amusements are exciting sports, theater-going, horse-racing, gambling, liquor drinking, and reveling. These stimulate every passion to intense activity. The youth are swept away by the popular current. ${ }^{1}$

One of the most subtle and dangerous temptations that assails the children and youth in the cities is the lure of pleasure. "Holidays are numerous; games and ... the whirl of excitement and pleasure attract them away from the sober duties of life. Money ... is frittered away for amusements." ${ }^{2}$ Children have a tendency to learn better from their peers than they do from adults. Ellen White pointed out that "it is Satan's purpose to attract men and women to the cities, and to gain his object he invents every kind of novelty and amusement, every kind of excitement. ${ }^{13}$ The children form evil associations that are unfavorable to the formation of right character. ${ }^{4}$ Ellen White urges believers to make it their lifework to seek spirituality and the restoration of God's image by beholding and studying God's handiwork. ${ }^{5}$

God wants His followers to be perfect in their life as the Son of Man was perfect in His life. ${ }^{6}$ The Christian character is more easily formed among the scenes

${ }^{1}$ Ellen G. White, Christ's Object Lessons (Washington, DC: Review and Herald Publishing Assn., 1941), 54.

${ }^{2}$ Ellen G. White, The Ministry of Healing, 364.

${ }^{3}$ Ellen G. White, MS 85, 1908, EGWRC-AU.

${ }^{4}$ Ellen G. White, The Desire of Ages, 136.

${ }^{5}$ Ellen G. White, MS 85, 1908, EGWRC-AU.

${ }^{6}$ Ellen G. White, The Desire of Ages, 311 . 
of nature than amid the wickedness of city life. ${ }^{1}$ She strongly stated: "There is not one family in a hundred who will be improved physically, mentally, or spiritually, by residing in the city." 2

Large churches

Another aspect of city life is that people gather together in large churches. Whether these large churches are in the city or the country, it is not God's plan, because there is a danger of members becoming spiritual weaklings. Ellen White expresses this thought beautifully when she compares the members of our large churches to trees that are planted too thickly to flourish. Many members of the large churches are dying spiritually and need to be transplanted so they will have room to grow strong and vigorous for the Lord. ${ }^{3}$

City: Object of God's judgment

God's people are called away from the threat of loss of life and property in time of disaster and war. Ellen White cries out: "O that God's people had a sense of the impending destruction of thousands of cities." ${ }^{4}$ And again: "Calamities will come, calamities most awful and most unexpected and these destructions will follow
${ }^{1}$ Ellen G. White, MS 141, 1899, EGWRC-AU.
${ }^{2}$ Ellen G. White, MS 76, 1905, EGWRC-AU.
${ }^{3}$ Ellen G. White, Testimonies for the Church, 8:244-245.
${ }^{4}$ Ellen G. White, Country Living, 8. 
one after another." ${ }^{1}$ The reason of God's judgment is to give an opportunity for the unwarned. "His hand is still stretched out to save, while the door is closed to those who would not enter. Large numbers will be admitted who in the last days hear the truth for the first time. ${ }^{22}$ God's judgment is to arouse their senses to a realization of the sinfulness of their course and idolatry, ${ }^{3}$ because the cities are full of transgression, sinful in the extreme, and given up to the possession of Satanic agencies. ${ }^{4}$ The means of God's judgment is "a terrible conflagration" by "great balls of fire,"5 "earthquake," "fire, "flood" "causing destruction, devastation, and death."6 As to the degree of God's judgment, "The Lord will not suddenly cast off all transgressors, or destroy entire nations." God will punish cities and places where individuals have given themselves up to the possession of Satanic agencies" ${ }^{17}$-. "pleasure resorts, theaters, hotels, and the homes of the wealth. ${ }^{18}$ For the sake of some souls who will yet break away from the delusions of the enemy, God will not

${ }^{1}$ Ellen G. White, Evangelism, 27. See also, Ellen G. White, Testimonies for the Church, 7:83.

${ }^{2}$ Ellen G. White to Brother and Sister Starr 1903, Letter 103, 4. EGWRC-AU.

${ }^{3}$ Ellen G. White, Testimonies for the Church, 9:92-93; Ellen White, Country Living, 8.

${ }^{4}$ Ellen G. White, Evangelism, 27.

${ }^{5}$ Ibid., 29.

${ }^{6}$ Ibid., 27.

${ }^{7}$ Ibid.

${ }^{8}$ Ellen G. White, Testimonies for the Church, 9:92. 
visit the wicked cities in the extreme of His indignation. ${ }^{1}$ For the time of God's judgment, Ellen White says, "The Lord has appointed a time when He will visit transgressors in wrath for persistent disregard of His law."2 The agent of judgment is the destroying angels of God at work. One touch, and buildings so thoroughly constructed quickly became heaps of rubbish. ${ }^{3}$ God's unseen agencies will cause destruction, devastation, and death. ${ }^{4}$

A part of the three angels' message in Rev 14

William Frazee developed the idea that the three angels' message of Rev 14 has to do with getting out of the cities. ${ }^{1}$ The first angel tells us what to come into as God led His people out of Egypt in order to take them into Canaan. In the country our hearts are readily inclined to worship Him who made the heaven and the earth. Surrounded by the works of man, cities are full of the spirit of Babylon--pride, competition, luxury, etc. The second angel selects a great city as a symbol of the kingdom of sin that rules this world.

This second angel's message is echoed by the loud cry of the angel of Rev 18 , with the admonition, "Come out of her, my people, that ye be not partakers of

${ }^{1}$ Ellen G. White, Evangelism, 27.

${ }^{2}$ Ellen G. White, Testimonies for the Church, 9:93.

${ }^{3}$ Ibid.

${ }^{4}$ Ellen G. White, Evangelism, 27.

${ }^{1}$ Frazee, "Out of the Cities: A Part of the Three Angels' Message," 1-7. 
her sins, and that ye receive not of her plagues." The reasons for getting out of Babylon are good reasons for getting out of the cities, in order to shun the evil atmosphere and avoid the cities' judgments.

The third angel warns against the beast, his image, and his mark. The beast and the image represent the great religious bodies which are to enforce upon the world the mark of the great apostasy. God's commandment-keeping, faithful believers are to "raise their own provision; for in the future the problem of buying and selling will be a very serious one."1

Eschatological calls

It seems that God's instruction to move out of the cities relates to three different periods in the history of the great controversy. ${ }^{2}$ The first call to leave the cities prior to the national Sunday law is not the general or universal call. City life is unfriendly religious life, ${ }^{3}$ and the cities of our world have become hotbeds of vice, ${ }^{4}$ physical dangers, and perils to health. ${ }^{5}$ God, therefore, wants His people to shun these surroundings. The second call relates to the national Sunday law which is the signal for all of God's people to leave the large cities for smaller ones:

${ }^{1}$ Ellen G. White, Country Living, 9-10.

2"Question 72: Is It Time for Us to Move to the Country?" 1990 E. G. White Estate, Washington, DC: Document File 303a, EGWRC-AU.

${ }^{3}$ Ellen G. White, Testimonies for the Church, 5:232-233.

${ }^{4}$ Ellen G. White, Medical Ministry, 363-364.

${ }^{5}$ Tbid., 365. 
The time is not far distant, when, like the disciples, we shall be forced to seek a refuge in desolate and solitary places. As the siege of Jerusalem by Roman armies was the signal for flight to the Judean Christians, so the assumption of power on the part of our nation, in the decree enforcing the papal Sabbath, will be a warning to us. It will then be time to leave the large cities, preparatory to leaving the smaller ones for retired homes in secluded places among the mountains (italics supplied). ${ }^{1}$

The third and last call will come when the close of probation comes. From that time on, Satan will have entire control of the wicked and the world, and God's Spirit will be withdrawn, and all the strife element will be released. ${ }^{2}$ The death decree will be issued and after a certain time the saints will be put to death. At the time of the close of probation, the saints of God will finally abandon the smaller cities and towns:

I saw the saints leaving the cities and villages, and associating together in companies, and living in the most solitary places. . . . I saw a writing, copies of which were scattered in different parts of the land, giving orders that unless the saints should yield their peculiar faith, give up the Sabbath, and observe the first day of the week, the people were at liberty after a certain time to put them to death. . . . As the Saints left the cities and villages, they were pursued by the wicked, who sought to slay them (emphasis supplied). ${ }^{3}$

During this time of trouble which will commence after the national Sunday Law, God's people will be filled with the Holy Ghost as they go forth and proclaim the Sabbath more fully, ${ }^{4}$ and God will provide all temporal wants for them.

${ }^{1}$ Ellen G. White, Testimonies for the Church, 5:464-465.

${ }^{2}$ Ellen G. White, The Great Controversy between Christ and Satan (Mountain View, CA: Pacific Press Publishing Assn., 1957), 613-614.

${ }^{3}$ Ibid., 282-285.

${ }^{4}$ Ibid., 33. 
The Lord has shown me repeatedly that it is contrary to the Bible to make any provision for our temporal wants in the time of trouble. . . . I saw that bread and water will be sure at that time, and that we shall not lack or suffer hunger; for God is able to spread a table for us in the wilderness. If necessary He would send ravens to feed us, as He did to feed Elijah, or rain from heaven, as He did for the Israelites. ${ }^{1}$

Economic situation of the last days

God's people are called away from the narrow occupational fields with labor problems. The trade unions, confederacies, labor unions, and strikes (1) will continue until Christ shall leave His place of intercession, ${ }^{2}$ (2) will bring a time of trouble such as has not been since the world began, ${ }^{3}$ and (3) are one of the signs of the last days. The unions are snares binding up men in bundles ready to be burned. ${ }^{4}$ Those who belong to these unions cannot keep the commandments of God, and those who refuse to join these unions will be marked individuals. ${ }^{5}$ Ellen White, therefore, warns that because troublous times are coming, God's people are to take their families away from the cities into the country where they can raise their own provisions. ${ }^{6}$

${ }^{1}$ Ibid., 56.

${ }^{2}$ Ellen G. White, Testimonies for the Church, 8:42.

${ }^{3}$ Ellen G. White, Country Living, 10.

${ }^{4}$ Ibid., 11.

${ }^{5}$ Ibid., 10.

${ }^{6}$ Ibid., 20-21. 
Caution to Those Who Anticipate

Leaving the City

The writings of Ellen White do not counsel that every Seventh-day Adventist should become a farmer, but she does urge that each family should possess a piece of land large enough to produce the family food supplies, which is quite another proposition. ${ }^{1}$

Ellen White warns: "More and more, as time advances, our people will have to leave the cities." As the way opens before them to do so, they will have to labor earnestly to help open the way. They should be most active in doing missionary work until it is possible for them to leave; they should not move in a rush, in an excitement, or in a rash manner. They should move with sincere prayer spreading every plan before God with fasting and humbling of the souls before God. ${ }^{2}$

There are other considerations which must be taken into account, such as how to support the family, education of children, personal witnessing, proximity to school, church, and availability of utilities, etc.

\footnotetext{
1"Seventh-day Adventists and the Country," [n.d.:n.d.], Document File 303, EGWRC-AU.

${ }^{2}$ Ellen G. White, Country Living, 24-28.
} 


\section{CHAPTER IV}

\section{BALANCING ACT: COUNTRY LIVING AND CITY MISSION}

Few would challenge the counsel of Ellen G. White concerning the vice, corruption, crimes, and unhealthfulness of city environment, and that the rural setting would be more favorable for us, particularly for families with children.

Unfortunately, the "unwelcome fallout from such counsel has been the notso-subtle adoption of an anti-city mind set by many Seventh-day Adventists." ${ }^{1}$ This negative attitude, Gottfried Oosterwal pointed out, is rooted partly in our cultural heritage of the nineteenth-century American frontier and partly in our theological understanding of God's revelation in Scripture and in the writings of Ellen White. ${ }^{2}$ Ellen G. White's heavy burden for cities shows that she was never anti-city in that she loved the people in the city, but did not recommend the physical and moral environment of the city.

\footnotetext{
${ }^{1}$ Myron Widmer, "The Challenge of the Cities," Adventist Review, March 12, 1992, 277:5.

${ }^{2}$ Oosterwal, "God Loves the Cities," 144:8.
} 
Instead of calling believers to move out of the city, she also urged "families that are well grounded in the truth" to "be scattered all over the country, in the towns, cities, and villages."1

In North America, Seventh-day Adventists have long debated city missions and country living. ${ }^{2}$ How can we resolve this apparent contradiction and tension between the counsel of Ellen White to leave the cities and to approach them by settling in the cities? The question about where we should live while we are on mission needs to be answered. This chapter deals with the methods of city mission to balance the two seemingly incompatible counsels given by Ellen White.

\section{City Mission: An Indisputable Counsel}

In 1910 Ellen White wrote: "The burden of the needs of our cities has rested so heavily upon me that it has sometimes seemed that I should die. ${ }^{13}$ Then only 15 percent of the world's population lived in the cities. Now the percentage of urban dwellers worldwide averages 45 percent. In America alone, the U. S. Census Bureau says that 77 percent of the population lives in the metropolitan areas. ${ }^{4}$ Repeatedly Ellen White challenged Seventh-day Adventists to address these

${ }^{1}$ Ellen G. White, Testimonies for the Church, 8:244-245.

${ }^{2}$ For example: Ted Wilson, "How Shall We Work the Cities--From Without?" and Gottfried Oosterwal, "How Shall We Work The Cities--From Within?" Ministry, June 1980, 18-22, 25.

${ }^{3}$ Ellen G. White, Evangelism, 34.

${ }^{4}$ North American Division Church Information System, 6 . 
tremendous needs that "have been cruelly neglected." ${ }^{1}$ In 1909 , she wrote, "O that we might see the needs of these great cities as God sees them!"2 How can this city mission be fulfilled while living in the country? Can SDA's preach the gospel in all the world while leaving the cities in order to move to rural districts? This section begins with a brief history of the early SDA city mission.

\section{Brief History of the Early}

SDA City Mission

The early history of the SDA city mission is briefly reviewed to show its original scope and history as a background of Ellen White's heavy burden of the needs of the cities.

The vision of Ellen G. White and the Oakland experience

In a vision while on the Pacific Coast in 1874, Ellen White listened to D. M. Canright and M. F. Cornell as they planned public meetings for the suburban towns of San Francisco, saying that it is best not to enter the large cities, but to work in small places, remote from the cities, in order to avoid the added opposition of the clergy of other denominations and to avoid greater financial expense. ${ }^{3}$ She also reported what God said: "The whole world is God's great vineyard. The cities and villages constitute a part of the vineyard. . . . It is to be given to all cities, to all

${ }^{1}$ Ellen G. White, MS 53, 1910, EGWRC-AU.

${ }^{2}$ Ellen G. White, Evangelism, 38.

${ }^{3}$ Ellen G. White, Testimonies for the Church, 7:34. 
villages. ${ }^{1}$ In harmony with this instruction, they dropped their plans for work in the small towns and went into the city of Oakland, California, holding a successful evangelistic series of meetings.

This vision and the Oakland experience marked a turning point in SDA evangelistic ministry. The large cities would now receive more attention in the efforts of the church. ${ }^{2}$

Original SDA city missions were not a type of welfare ministry to the underprivileged and the outcasts, but were in scope and practice the prototype of the modern evangelistic centers. Describing the mission in Chicago in 1884, J. H. Waggoner said: "Our mission there, as in other cities, is very different from what are generally known as 'city mission.'"13

Emphasizing the importance of the specialized training centers in the city, Ellen White wrote in 1887 that the Bible workers cannot take hold of this work "unless they are prepared for it. ${ }^{4}$ Again burdened with the magnitude of New York City, she counseled in 1901 that more than "consecrated evangelists were

'Ibid., 7:34-36.

${ }^{2}$ Arthur L. White, "Adventist Responsibility to the Inner City," Review and Herald, November 5, 1970, 2.

${ }^{3}$ John H. Waggoner, "Chicago Mission," Review and Herald, December 23, $1884,807-808$.

${ }^{4}$ Ellen G. White, Fundamentals of Christian Education, 121. 
needed. . . . City mission must be established where colporteurs, Bible workers, and practical medical missionaries may be trained to reach certain classes."1

Pioneer city missions were opened in New York, Chicago, and San Francisco. E. W. Farnsworth reported in 1888 that there were twenty-two city missions in operation. The first SDA church in Washington, D.C., was the direct result of a city mission. A thousand new members were added to the total world membership of 27,000 in 1884 through the city mission in four years. ${ }^{2}$

In spite of financial difficulty, Ellen White never lost sight of the unique value of the city mission with dual objectives of training workers and gaining converts. In 1901 she wrote:

In every city there should be a city mission, that would be a training school for workers. . . . If our brethren will use their God given ability to warn the cities, angels of God will surely go before them to make the impression upon the hearts of the people for whom they labor. ${ }^{3}$

Working for the underprivileged

The SDA city mission was predominantly evangelistic in its thrust, aimed for the most part at reaching the middle and higher classes. The poor and the destitute were assisted as needed by the team, and treatment was given by nurses to

${ }^{1}$ Ellen G. White, Testimonies for the Church, 9:137.

${ }^{2}$ General Conference of Seventh-day Adventists (Washington, DC), Daily Bulletin of the General Conference Committee, 1888 (No. 8, p. 2), Ellen G. White Research Center, Andrews University, Berrien Spings, MI.

${ }^{3}$ Ellen G. White, Medical Ministry, 303-304. 
those who needed it. But this was not the principal objective of the mission. ${ }^{1}$

Following in the footsteps of Jesus who went about doing good, SDAs often heard the challenge to assist materially those who were pressed for want of means. Ellen White, however, maintained in a letter to J. H. Kellogg that revenue of the churches was not to be appropriated to this work and that those who engage in that work should draw their means largely from those outside of our faith, so that they shall not neglect the need of the work all over our world. ${ }^{2}$

\section{Dr. John Harvey Kellogg}

From the 1880 s to the early part of the twentieth century, an unprecedented interest in the poor and outcasts developed in the United States among many Protestant churches, which had soon become known as the social gospel movement. Groups such as Charity Organization Societies, the Settlement House Movement, and Visiting Nurses' Association sought relief for the ill, the hungry, and the underprivileged. $^{3}$

In the early 1890 s, Dr. John Harvey Kellogg, the highly respected medical superintendent of the Battle Creek Sanitarium and the natural leader of the medical work of the SDA, greatly admired Dr. George D. Dowkontt, a New York physician who aspired to a Christian medical uplift work that operated apart from the ties of any

'Arthur L. White, "Adventist Responsibility to the Inner City," 4.

${ }^{2}$ Ellen G. White to Dr. J. H. Kellogg, 1899, Letter 4, EGWRC-AU.

${ }^{3}$ Arthur L. White, "A Shift in Emphasis," Review and Herald, November $12,1970,7$. 
particular church, and became deeply interested in the downtrodden, the destitute, the outcasts, the harlots, and the drunkards in our large cities. ${ }^{1}$

When in 1895 the denomination launched a medical school, the American Medical Missionary College, Dr. Kellogg, who led out in the project, envisioned the school as an agency for the training of physicians for such a social work, following Dr. Dowkontts's medical college where more than eighty-two physicians were training for such services. He slowly developed a plan for a great popular nondenominational Christian medical work by using SDA

medical resources. In announcing the opening of the American Medical Missionary College in 1895, Dr. Kellogg spoke to the students: "This is not a sectarian school. Sectarian doctrines are not to be taught in this medical school. . . . It is not to be either a Seventh-day Adventist or a Methodist or a Baptist, or any other sectarian school."2

The Seventh-day Adventist Medical Missionary and Benevolent Association, created in February 1893 by an act of the General Conference, had succeeded the earlier Health and Temperance Association. By 1896, captivated by Dr. Dowkontt's organization's terminology--International Medical Missionary Society--Dr. Kellogg changed the first part of the name from "Seventh-day Adventist" to "International," under the pretext of accommodating the expanding work for the church. But the real

${ }^{1}$ Dores E. Robinson, The Story of Our Health Message (Nashville, TN: Southern Publishing Assn., 1965), 275. See Arthur L. White, "A Strategy of Diversion," Review and Herald, November 19, 1970, 8.

${ }^{2}$ Robinson, The Story of Our Health Message, 294-295. 
reason of the change was disclosed in 1898 when Dr. Kellogg explained the work of this association:

The International Medical Missionary and Benevolent Association is a unique organization in the fact that it is, as far as we know at least, the only association which has undertaken to organize and carry forward medical and philanthropic work independent of any sectarian or denominational control, in home and foreign lands (emphasis supplied). ${ }^{1}$

With full confidence in Dr. Kellogg's direction, church leaders asked him to draw up the papers for the new charter, the document which stated that "all of its works and acts were to be undenominational and unsectarian, purely charitable, benevolent, Christian, and philanthropic (emphasis supplied)."2

This shift of emphasis, introduced almost imperceptibly in the denominational medical work, did not go unnoticed by God. The matter was opened up to Ellen White in vision, and she wrote Dr. Kellogg a letter which says:

You were letting go the banner of Seventh-day Adventists, reaching out to grasp the banner presented to you. . . . I was instructed that you and your fellow laborers were in danger of hiding the principles of our faith in order to obtain large patronage. ... And there must be no covering up of any phase of our message. . . . The peculiarities of our faith will appear, distinguishing us from the world. . . . In no case is principle to be sacrificed or the peculiar characteristics of our faith hidden in order to add outside students to our class. ${ }^{3}$

${ }^{1}$ Ibid., 293.

${ }^{2}$ Ibid., 327.

${ }^{3}$ Ellen G. White, Testimonies for the Church, 8:153-157. 
Diversion of the city mission

and resources

This shift of emphasis by the leader of the Adventist medical work resulted in a decade of crisis, which gradually brought in a diversion of mission and human and financial resources. Ellen White emphasized the denomination's unique and distinctive messages for the whole world, while recognizing the Battle Creek Sanitarium was undenominational in its service for all people.

Now and ever we are to stand as a distinct and peculiar people, free from all worldly policy, unembarrassed by confederating with those who have not wisdom to discern the claims of God, so plainly set forth in His Law. ${ }^{1}$

As to the work in Chicago's inner city, Ellen White repeatedly emphasized the importance of teaching the new converts the requirements of God's holy law.

In all our work the law of God must be presented; with its far-reaching requirements, to lead men and women and youth to see the need of loyalty to God. The efforts put forth to rescue degraded outcasts will not be of any avail unless the claims of the law of Jehovah are imprinted on mind and heart. ${ }^{2}$

For the work in Chicago, too great an effort in feeding and too much money in doing slum work were spent, and the ministry of gospel and medical ministry work in general suffered at home and abroad. About the misappropriation of means, Ellen White declared: "It is the plan and constant effort of Satan to entangle

${ }^{1}$ Ellen G. White to Dr. J. H. Kellogg, 1902, Letter 128, EGWRC-AU, quoted in Robinson, The Story of Our Health Message, 298.

${ }^{2}$ Ellen G. White, MS 150, 1899. 
the work of God in a supposed beneficent and excellent work, so that doors can not be opened to enter new fields." 1

In 1900, Ellen White wrote a letter to Elder and Mrs. Haskell who were starting the work for the disadvantaged in New York City.

None are required to establish a work in any city which gives to an indiscriminate class an invitation to be supported by the charities of the Seventh-day Adventist people, whose special work is to bear an unpopular message to the world. The commission is given to bear the message to all nations. $^{2}$

In letters to G. A. Irwin, president of the General Conference, Ellen White stressed that the means should not be used in doing the work that the world would do largely, for the world will not do the work which God has committed to His people; ${ }^{3}$ "it is not the Lord's Spirit that has inspired you to take up the work which other churches will do." ${ }^{4}$

But the appeals and warnings seemed to have been rejected. The everenlarging undenominational work for the downtrodden and the outcasts was extolled and promoted. This resulted in the diversion of human resources and financial support.

${ }^{1}$ Ellen G. White, MS 46, 1900, EGWRC-AU, quoted in Ellen G. White, Temperance, 222.

${ }^{2}$ Ellen G. White to Elder and Mrs. Haskell, 1900, Letter 90, EGWRC-AU.

${ }^{3}$ Ellen G. White to G. A. Irwin, 1900, Letter 3, EGWRC-AU.

${ }^{4}$ Ellen G. White to J. H. Kellogg, 1900 Letter 45, EGWRC-AU. 


\section{Paradox of SDA Mission}

Oliver Goldsmith wrote, "God made the country, man made the town." That distinctly anti-city attitude is shared by many Seventh-day Adventists as shown in chapter 2. Can Seventh-day Adventists preach the gospel in all the world while living in the country? With today's emphasis on rural living, it is relatively easy to forget the people trapped in the dense urban jungles, and to become calloused to their cry for understanding and deliverance. When on earth, our Lord spoke with deep concern about the cities. "And Jesus went about all the cities and villages, teaching . . . preaching . . . healing. . . . But when he saw the multitudes, he was moved with compassion" (Matt 9:35, 36).

\section{Great Needs of the Cities}

Seventh-day Adventists, charged with the task of taking the everlasting gospel to every nation, kindred, tongue, and people (Rev 14:6,7), cannot ignore city mission. Ellen White wrote in 1910:

The spiritual darkness that covers the whole earth today, is intensified in the crowded centers of population. It is in the cities of nations that the gospel worker finds the greatest impenitence and the greatest need. ${ }^{1}$

In 1910, it was the intention of A. G. Daniels, then General Conference president, to call on Ellen White and review with her a proposed meeting with evangelists in New York City. To his surprise and dismay, Ellen White flatly refused to see him until he should personally lead out in the work of evangelism in a manner

${ }^{1}$ Ellen G. White, Evangelism, 25. 
to inspire complete denominational commitment. This rebuke was a traumatic

experience for A. G. Daniels, as he later revealed to a group of Australian ministers:

She [Ellen White]. . . sent messages to me regarding the work in the cities in the Eastern States. I seemed unable to understand them fully. Consequently I did not do all that these messages indicated should be done. Finally I received a message in which she said, "When the president of General Conference is converted, he will know what to do with the messages God has sent him." . . . I have since learned that we need to be reconverted now and then. ${ }^{1}$

Country living seems to be more attractive. But the fact is that cities--the people who live in them--have great needs. Over and over again, Ellen White challenged Seventh-day Adventists to address these needs. In 1909, for example, she wrote, "Oh that we might see the needs of these great cities as God sees them!"2

In the Scriptures, Paul, the apostle to the Gentiles, lived, worked, and preached in such great cities as Antioch, Philippi, Thessalonica, Athens, Corinth, Ephesus, and Rome. While the cities are centers of the gathering together of human achievement and creativity, they also embody the worst features of human corruption. Corinth had even lent its name to describe wanton conduct. In the society of Paul's day, to "corinthianize" signified casting off all restraints, abandoning oneself to dissolute, profligate behavior.

Ellen White said, "My duty is to say that God is earnestly calling for a great work to be done in the cities. ${ }^{13}$

${ }^{1}$ A. G. Daniels, Australian Record, August 13, 1928, 1.

${ }^{2}$ Ellen G. White, Evangelism, 38.

${ }^{3}$ Tbid., 37. 


\section{Difficult Situation}

The action voted by the October 1978 Annual Council of the General Conference Committee ${ }^{1}$ suggested a rural setting for church institutions, for those lay persons and employees doing evangelistic work in the cities, and for those members not involved in such evangelistic work. ${ }^{2}$ Ellen White in 1906 wrote, "Out of the cities; out of the cities! . . This is the message the Lord has been giving me. ${ }^{13}$ But the cost of relocation is often prohibitive. Church schools, hospitals, food companies, publishing houses, and conference headquarters, many of which originally were built in the country, have now been overrun by expanding cities. Furthermore, how can we relocate a school in the country when the pupils are living in the city and parents' homes and work are in the city? Generally, and especially in Korea, cities are growing larger and more dense, while rural areas are rapidly losing their population.

To move into the country would virtually remove a Seventh-day Adventist from any opportunity to witness the gospel. To make a living on a family farm is fast becoming an economic impossibility. This difficult situation must be resolved, and the question of how to work the cities while living in the country needs to be answered.

${ }^{1}$ This SDA Annual Council of the General Conference Committee was held in Takoma Park, Maryland, October 10 to 18, 1978.

${ }^{2}$ White and Sutherland, From City to Country Living, 62-64; Actions of the 1978 Annual Council of the General Conference Committee of SDA (Washington, DC), October 10-18, 1978, 23-25, EGWRC-AU.

${ }^{3}$ Ellen G. White, Life Sketches, 409. 
Resolving the Tension

Ellen G. White emphasized the evangelization of the cities, but also stressed a simple lifestyle, preferably in a rural setting. This implies that the city is people who are the object of God's love and that the city is an evil, unhealthful environment to avoid. This tension needs to be resolved creatively.

Not either/or but both aspects of the cities

Adventists, especially in North America, have had a negative attitude toward the cities and have condemned the city as evil; as an expression of man's revolt against God; as a center of wickedness and immorality, human arrogance, and pride; and as a demoniac threat not only to the church and to the believers' salvation, but to civilization at large. The only safe course for the believers, therefore, is to avoid the city and to leave those centers "where the enemy is served in every way, and where God is so often forgotten." ${ }^{1}$ This anti-city attitude is also rooted in the Bible and in the writings of Ellen White.

The first city the Bible mentions is Enoch, built by brother-murderer Cain (Gen 4:17). It stands as a symbol of human rebellion against God and of man's attempt to construct his own world in defiance of God's will and purpose for humanity. The development of cities after the Flood confirms this view. Babylon, founded on human arrogance and pride, and in direct defiance of God's will (Gen 11:4ff), came to symbolize confusion, pride, and revolt against God. Sodom, a city

${ }^{1}$ Ellen G. White, Life Sketches, 410. 
so wicked that God could not find even ten righteous people in it (Gen 18:32), became a synonym for depravity and perversity.

The prophets Jeremiah, Ezekiel, Isaiah, and Micah constantly urged the cities to change their evil ways or else expect total destruction. These prophetic utterances against cities in Scripture find their climax in the description of God's judgment over Babylon, the most wicked city of all. The apostle John urged the people of God to come out of that city and have nothing to do with its spirit and activities (Rev 18:4).

Ellen White states that "those who departed from God built for themselves cities, and congregating in them, gloried in the splendor, the luxury and the vice that makes the cities of today the world's pride and its curse."1

But Scripture presents another view of the city. The city can be a center of God's presence, power, and peace; an instrument of his mercy and protection; a symbol of salvation and redemption. Jerusalem, the city of peace, stands throughout the Bible as the symbol of God's church and His salvation. God nowhere condemns the city, per se, as evil. God Himself, in Old Testament times, commanded His people to build cities and suburbs.

Most well known are the cities built for the Levites to live in as part of their sacred heritage (Num 35:8) and the cities of refuge, where people guilty of manslaughter might flee and be safe until they could get a fair hearing (Num 35:9-15; Deut 4:41-43; Josh 20). These cities, built for Israelites and foreigners, were so

${ }^{1}$ Ellen G. White, Education, 34. 
located upon the specific command of God, that no one needed to travel more than thirty miles in order the reach them.

Here the city is not a symbol of evil, founded upon human pride, greed, or revolt. It stands as a sign of God's mercy and justice, established by an act of His grace and compassion.

So the prophet urged the believers to pray for the city, even for Babylon, where they were held captive (Jer 29:7). God gave His people a detailed blueprint for the building of their "great city," a symbol of the heritage of God's grace for all people, and named it "The Lord is There" (Ezek 48:35). God had mercy for Nineveh, "that great city" (Jonah 4:11). The Psalmist describes the pilgrimage of God's people as that of a hungry wanderer searching in the desert for a city that God provides as a deliverance from distress (Pss 107:4-8; 122:3-7).

All of these aspects of the city--refuge, redemption, safety, security, peace, and prosperity--find their final fulfillment at the end of time, when the New Jerusalem, that splendid city whose founder and builder is God, will descend from heaven, adorned as a bride. The center of the new earth is not a garden, or a new paradise, but a city (Rev $21: 24-26)$. Thus every city has the potential of becoming a place of refuge and redemption or a pool of evil and oppression.

The modern cities reflect these two aspects of the ancient cities. The believers, therefore, must flee those evils, not only by moving into the rural areas, especially for children, but also by drawing closer to God, by a greater dependence on His Spirit, and by a deeper involvement in witnessing so that the city becomes 
indeed a better place, a center of justice, peace, and redemption. Each city on earth has the potential of becoming a place of refuge and redemption.

Not either/or but both

within and without

Ellen White states that sanitariums, schools, ${ }^{1}$ and institutions ${ }^{2}$ are to be established "just out from" and "in easy access to, the large cities, ${ }^{3}$ while having "houses of worship as memorials for God" in the cities. ${ }^{4}$ From the rural outposts, workers come into the city to labor in vegetarian restaurants, health-food stores, ${ }^{5}$ local church evangelism, house-to-house evangelism, public evangelism, literature evangelism, ${ }^{6}$ and medical missions. ${ }^{7}$ The reasons for these methods of outpost evangelism, she mentions, are "the trade unions and confederacies," "strife and confusion, ${ }^{18}$ and "increasing wickedness in the great cities,"9 and the earthquakes and floods. ${ }^{10}$

${ }^{1}$ Ellen G. White, Medical Ministry 14, 308.

${ }^{2}$ Ellen G. White, Country Living, 30.

${ }^{3}$ Ellen G. White, Medical Ministry, 308, 309.

${ }^{4}$ Ellen G. White, Country Living, 31.

${ }^{5}$ Ellen G. White, Medical Ministry, 306.

${ }^{6}$ Ellen G. White, Testimonies for the Church, 7:37.

${ }^{7}$ Ellen G. White, Medical Ministry, 37.

${ }^{8}$ Ellen G. White, Selected Messages, 2:142.

${ }^{9}$ Ellen G. White, Country Living, 25.

${ }^{10}$ Tbid., 31. 
A strong emphasis on outpost evangelism and on making wise plans for it

are as follows:

The cities are to be worked from outposts. Said the messenger of God, "Shall not the cities be warned? Yes; not by God's people living in them, but by their visiting them, to warn them of what is coming upon the earth." . . . Repeatedly the Lord has instructed us that we are to work the cities from outpost centers. . . . We must make plans to warn the cities, and at the same time live where we can shield our children and ourselves from the contaminating and demoralizing influences so prevalent in these places.'

However, Ellen White did not necessarily look upon country living as a

withdrawal or isolation from the cities. She wrote in 1868,1891 , and 1903

respectively:

Brethren who wish to change their location, who have the glory of God in view, and feel that individual responsibility rests upon them to do others good, to benefit and save souls for whom Christ withheld not His precious life, should move into towns and villages where there is but little or no light and where they can be of real service and bless others with their labor and experience. Missionaries are wanted to go into towns and villages and raise the standard of truth, that God may have His witnesses scattered all over the land (emphasis supplied). ${ }^{2}$

We see the great need of missionary work to carry the truth not only to foreign countries, but to those who are near us. Close around us are cities and towns in which no efforts are made to save souls. Why should not families who know the present truth settle in these cities and villages, to set up there the standard of Christ, working in humility, not in their own way, but in God's way, to bring the light before those who have no knowledge of it? When the church shall truly have the spirit of the message, they will throw all their energies into the work of saving the souls for whom Christ has died. . . . There will be laymen who will move into towns and cities, and into apparently out-of-the-way places, that

${ }^{1}$ Ibid., 30-31.

${ }^{2}$ Ellen G. White, Testimonies for the Church, 2:215. 
they may let the light which God has given them, shine forth to others (emphasis supplied). ${ }^{1}$

The disciples of Christ are His representatives upon the earth, and God designs that they shall be scattered all over the country, in the towns, cities, and villages, as lights amidst the darkness of the world. . . . None should move into new places merely for the sake of worldly advantage; but where there is an opening to obtain a livelihood, let families that are well grounded in the truth enter, one or two families in a place, to work as missionaries (emphasis supplied). ${ }^{2}$

Ellen White counsels the believers not to isolate themselves from the people of the cities, but to live among them and to mingle with them, to show interest in their daily affairs.

Christ's method alone will give true success in reaching the people. The Savior mingled with men as one who desired their good. He showed sympathy for them, ministered to their needs, and won their confidence. Then He bade them, "Follow Me."

She writes that "the followers of Christ at Antioch should be an inspiration to every believer living in the great cities of the world today. ${ }^{14}$

How can this apparent contradiction be resolved between the counsel given by Ellen White to leave the cities and to approach them by proxy and from outpost centers and the counsel that families who know the present truth should settle in the cites, towns, and villages to set up the standard of Christ? It seems that the whole

'Ellen G. White, "Missionary Work," 2:521, quoted in idem, Christian Service (Hagerstown, MD: Review and Herald Publishing Assn., 1967), 180.

${ }^{2}$ Ellen G. White, Testimonies for the Church, 8:244-245.

${ }^{3}$ Ellen G. White, Ministry of Healing, 143.

${ }^{4}$ Ellen G. White, The Acts of the Apostles (Mountain View, CA: Pacific Press Publishing Assn., 1911), 158. 
biblical message concerning the city, not one or the other, but both its negative and positive aspects, should be accepted.

First, an anti-city attitude leads to an utterly truncated form of mission, leaving the majority of the more than two billion people in the cities today without a powerful witness of Christ and His gospel. The pro-city attitude could place us in danger of losing sight of its evil and demoniac threat. ${ }^{1}$

Second, every situation must be evaluated on its own merits, since there is not a blanket guideline given in Scripture and in the writings of Ellen White that covers every circumstance. It seems, therefore, that Arthur White and E. A.

Sutherland suggested well regarding moving into the country:

The family background, whether or not there are children, the ages of the children, the educational needs, the occupational skills, together with opportunities and special aptitudes for missionary work, are all factors that enter into determination of the case of each family as to just what constitutes country and the degree of isolation desirable. ${ }^{2}$

Another consideration is that the city is not just a geographical unit, for the "spirit of the city" is not tied to a particular place. The city is a way of life, a culture, with its own values and way of thinking, relating, and behaving. These aspects of the city can be changed by those who "are well grounded in the truth." "The spirit of the country can be had in the city if we choose to create and nurture " while "a country home may still be filled with the 'spirit' of the city. ${ }^{13}$ For that

'Oosterwal, "God Loves the Cities," in 10.

${ }^{2}$ White and Sutherland, From City to Country Living, 19-20.

${ }^{3}$ Ritchie Way, "The Paradox of Our Mission," Adventist Review, August 9, 1990, 10. 
reason God sent Jonah to Ninevah--the doomed city (Nah 3:5-7), not as an isolator (Jonah 1:1-3), but as a transformer (Jonah 3:1-10).

In the cities, the great controversy between Christ and Satan is most powerfully displayed in the forces of destruction, persecution, unbelief, and wickedness on the one hand, and the powers of creativity, progress, religious freedom, commerce, science, industry, social justice, etc., on the other.

In order to fulfill Christ's commission, it seems necessary that we live where people live--in the cities, towns, and rural areas. Although technology has advanced as cities have grown, the largest cities today require hours to cross.

Those who live in the city and those who want to move to the cities should be encouraged to choose their apartments or houses wisely. Many can find places and ways to live that reduce stress, the hectic pace, and physical danger that often accompany city life. For the sake of providing a more natural environment for growing children, some families will want to move from the city to the country or the suburbs.

Those who move to the country or suburbs, of course, cannot be guaranteed either physical or moral safety. Senseless crimes and disasters strike anywhere. Radio, television, and videos can instantly bring the city right into a country home. Factors that constitute a good home certainly include its environment and setting. Ultimately, though, a good home is built upon the principles and ideals that parents foster within it. City evangelism should be carried forward by combined forces of those who live in the city and in the country. 


\title{
CHAPTER V
}

\section{DESIGN AND ADMINISTRATION OF THE INTERVENTION}

\author{
AND ITS EVALUATION
}

\section{Design and Administration}

In order to improve the understanding and practice of country living, this chapter deals with a intervention in the form of a workshop. The workshop was held on March 13, 1993 (Saturday afternoon), in the Georgia Central Korean SDA

Church. An announcement was made two weeks prior to the workshop. Forty-two SDA members ${ }^{1}$ participated.

Just before the first workshop, Survey 1 (see appendix 1) was distributed to the congregation and collected after they filled it out. The first session of workshops was given on the "Historical Background of the SDA Country Living Movement in Urbanizing America and Korea" (see appendix 4). In this workshop, the discussion on the social climate, especially the anti-urban attitude that was one of the predominant trends among contemporary intellectuals, in the time of Ellen G. White,

${ }^{1}$ This number represents 30 percent of the Georgia Central Korean SDA Church members. The detailed personal background such as their age, gender, etc., is shown in Appendix 2 (Question 17 or Survey 2). 
was constructive for all the participants to reexamine their former concept of country living.

One of the prime purposes of this session was to clarify the origin and sources of the messages on the subject of country living. Another main purpose was to assist the participants to be aware of the various responds to the country living message that have appeared in the SDA history. By comprehending these responds since the message was given, the participants were exposed to both positive and negative impacts that have influenced the SDA Christians. After giving the lecture according to the outlines, a question-and-answer period was given for free discussion. Some facts needed to be verified to the inquire by reading the quotations from the literature of various authors.

During the next session (appendix 5, "Ellen G. White's Understanding on City Living and Country Living"), an attempt to have the correct perception of the Ellen White's definition of the word, "city", was made. After this process, almost all participants expressed that they needed to change their previous understanding of the Ellen White's definition of the word "city." In this session, a debate that dealt with the questions of how Ellen G. White understood the word, "country" and of how Ellen G. White distinguished between "country" and "city". A balanced and correct explanation based on the writings of Ellen G. White played a significant role in answering these questions.

The final session, "Balancing Act," (see appendix 6) where the existing tension between city evangelism and country living was fiercely argued, was the 
climax of this workshop. None of the participants denied the importance of the city evangelism. At the same time, they were fully aware of the benefits of living in the country. In order to eliminate this tension, all the participants agreed to the fact that the evangelism for city is to be accomplished by the believers living both "within" the cities and at outskirts of the cities. Having agreed on the most suitable location for the city evangelism, all the participants emphasized the importance of having strong faith in God in order to carry out such an imperative task of evangelizing the city.

\section{Evaluation}

The results of Survey 1 show that 74 percent of the respondents gave correct answers. The reason for such a relatively high percentage of getting the correct answers is due to the fact that the participants was already taught by the writer of this project. The reason for the education was to prevent them from being indoctrinated with false views on the issue by a group of Korean SDA church members who had come to Athens in Georgia in 1988 in order to pursue the country life. As mentioned in chapter one, this group has had an extreme and dogmatic position in understanding and practicing the message of country living. Because of their extreme approach, the Georgia Central Korean SDA church members who did not have a fair understanding on the matter, began searching for the correct concept of the country living.

The fact that the percentage of getting the correct answers increased from 74 to 85 in the Survey 2, indicates that the workshop had an impact on deepening their understanding of country living. Thus, the analysis of results from the two 
surveys is needed to measure the effectiveness of the workshop.

Due to the reason that most of the participants had a misconception of the word, "country", it was crucial to reinforce the true meaning of this word before any debate on the subject had begun. Thus, comparing the two different results of the first question from the Survey 1 and 2, presents the effectiveness of the workshop. The percentage of getting correct answers for the first question of both Survey 1 and 2, which measures the level of understanding of "country" as meant by Ellen White, jumps from 14 percent to 62 percent, reflecting a significant change in their concept of "country".

The second question that uncovers the participants' understanding of the most suitable location for the country living and the fourth question that deals with the reason for moving to the country, show that there were no major disputes in determining where the location should be and why they should leave for country among the participants.

One of the reasons why 95 percent of participants correctly answered the third question of the first Survey, was due to the fact that they had witnessed the group of Korean SDA members in Athens that came to the country without considering many factors pertaining to the country living and against to the advice of church leaders.

From the fifth question, which reflects the relationship between the country living and the enforcement of the National Sunday Law, two-third of the participants believe that the enforcement of the National Sunday Law is the clear and final signal 
for them to leave large cities and move to country.

In order to ascertain the participant's perception about the modern city and their understanding of God's judgment on the city, the sixth and eighth questions were placed in two Surveys. According to the results of the Surveys, the majority had a fair view of modern cities and God's judgment on them.

Another important aspect of the Surveys was to draw a conclusion on the matter of the relationship between country living and salvation. Thus, the result of the seventh question that reflects the participants' balanced view on this relationship is an important finding for the project. However, one participant was added to answer "a" at the Survey 2. This result indicates that there was too much emphasis on the negative aspects of the city life, especially its harmful influence on the Korean SDA Christians during the workshop.

Although the participants have been exposed to the city's forceful influence on their Christian life, 70 percent of those who answered question nine believe that the final decision on the matter of whether one should leave city or not ought to be made individually.

"Who should evangelize the city people" (question 10) and "how should this message of warning be done?" (question 11) are natural questions to put forward before the participants. Seventh three percent believe that evangelism for the city population ought to be accomplished by every Christian regardless of where they live. At this point, one should recognize an important aspect of the city evangelism. That is the different demographic setting when compared between the Ellen G. White's 
period and present. At the time of Ellen G. White, 85 percent of the population was living in the rural area and had access to the cities that were built around small towns and villages (see chapter IV). In other words, the concept of the country living was much easier to accept for those who lived at that period. However, 77 percent of the American population is now living in the metropolitan areas. Thus, applying the message of the country living to modern Christians in the exactly same manner that were used by Christians who lived several decades ago, is impossible. Because 83 percent of the participants realized this kind of change, they are convinced that establishing "outpost centers and memorials" are the most practical approach in evangelizing the city population. Because of this conviction, the majority of the participants who chose "rural districts, in easy access to the cities" (question 13, b) as the suitable location for our institutions, answered as expected.

The 16 percent increase from 74 percent in the results of question 12 , Survey 1 , reveals that the counsels of Ellen G. White regarding the question of who should settle in the cities were addressed during the workshop.

Question 14 was constructed in order to determine one of the main reasons why parents leave for the country. The result of this question imply that the majority of the parents would leave the city for the country for the sake of their children's mental, physical, and spiritual growth.

One of the most visible achievement for the workshop is the increase percent from 45 to 62 for question 15 . According to the results of Survey 1, almost half of the participants tended to have a naive attitude toward country living. For this 
reason, the realistic factors that should be considered before leaving for country, were re-emphasized throughout the workshop. In spite of this re-emphasized on the realistic aspects of country living, there are 16 participants who still persist to have the same naive view on the issue.

The overall improvement from the workshop is reflected in question 16 or Survey 2 when 90 percent of the respondents indicated that they had a better understanding about the issues.

Graphs depicting these statistics are included in appendix 7. In appendix 1 and 2, the percentage of right answers is written beside the correct answer. 
CHAPTER VI

CONCLUSION

The anti-urban attitude in the writings of Ellen G. White has significantly influenced the Adventists in North America and Korea. The message of country living throughout the writings of Ellen G. White does not necessarily mean isolation from the populated cities, but means a natural environment for the believers' spiritual, physical, and intellectual culture.

The more positive and creative approach to the message of country living and its application is not leaving the city and moving to the country without an intention of working in the city, but abandoning the "spirit" of the city by drawing close to God. This is maintained by an active devotional life, and by deeper involvement in working for others' salvation so that the city becomes indeed a better place, a center of justice, peace, and redemption. God saw this potential of the city when He sent Jonah to Ninevah (Jonah 1).

Ellen G. White also sends the "families who are well grounded in the truth" to "settle in these cities and villages, to set up there the standard of Christ."1 The believer must resist and reject the "spirit" of the city-- greed, self-reliance,

${ }^{1}$ Ellen G. White, Testimonies for the Church, 8:244-245; Ellen G. White, Christian Service, 180. 
ambition for power, pride, licentiousness, and wicked entertainment of selfindulgence, etc., through the transforming power of the Holy Spirit in diligently working for the people for whom Christ died.

The congested, crowded areas of the cities are to be worked in from outposts and suburbs in order to "shield our children and ourselves from the contaminating and demoralizing influences so prevalent in these places. ${ }^{2}$ By choosing apartments or homes wisely, there are ways to embody the spirit of country living within the city. Every situation must be considered on its own merits. The location of the home should be determined by the family background, the age of the children if any, the educational needs, the occupational skills, and the missionary zeal, ${ }^{3}$ until the enforcement of the national Sunday law. ${ }^{4}$ Country living is desirable, but it is not complete without working for the salvation of other people. Believers are born for missionary work. Thus, the extremists who claim that every SDA Christian must leave the city and live in the mountains without considering the realistic aspects of life such as children's education beforehand; and who also assert no need for evangelism because of the imminent second coming of Jesus Christ, are opposite to the counsels of Ellen G. White. In addition, this group of extremists tends to threaten congregations that belong to established SDA churches, with the claim that the cities will soon be destructed by God like Sodom and Gomorrah. These extremists thus

${ }^{2}$ Ellen G. White, Country Living, 30-31.

${ }^{3}$ See White and Sutherland, From City to Country Living, 19-20.

${ }^{4}$ Ellen G. White, Testimonies for the Church, 5:464-465; Ellen G. White, Early Writings of Ellen G. White, 282-285. 
urge to leave cities in order to be saved from eternal damnation. Because of such urgency to leave cities, the extremists do not give people much time to consider carefully about the country living.

Those who have responded to this call to come out of the city and move to the country, had to first face a natural consequence of not being prepared for the harsh country living which some of them could not bear through. The next difficulty is in finding a job through which one can earn his necessities such as food. For many cases, these difficulties eventually lead the people who came to the country without much preparation and resulted in a total surrender of their Christian faith. Therefore, the writer of this project perceives these extremists as those who lead the SDA Christians astray.

One primary role of the pastor is to help the church members discover their own gifts and needs, and to find solutions to their needs through education. Only the member can choose his or her needs and solutions. The members should not be forced to leave the city and move into the country. "The task of the leader is to help create the conditions under which members will decide to activate themselves. ${ }^{15}$ Through the education of country living, the misapplication of the message of country living can be prevented.

The initiation of an intentional form of ministry within the Georgia Central Korean Seventh-day Adventist Church was successful in facilitating the message of

\footnotetext{
${ }^{5}$ Robert C. Worley, Dry Bones Breathe! (Chicago, IL: Center for Their Study of Church Organizational Behavior, 1978), 69.
} 
country living into comprehensive understanding. The efforts and time invested into the work have resulted in growth on my part as well as on the part of the church. In order to prevent the church members of the Georgia Central Korean SDA Church from the false teachings about the country living that have been taught by the extremists in the Atlanta area since 1988, the writer of this project managed to teach the wholistic view on the subject to the church members before anyone of the members was indoctrinated by the false teachings. Hence, both the writer of this project and the members of the Georgia Central Korean SDA church are now able to distinguish between true and false teachings about the country living.

As far as the Georgia Central Korean SDA Church is concerned, none of the members has joined the extreme group. On the contrary, two families were able to leave the extreme group and became the members of the Georgia Central Korean SDA Church. Thus, obtaining the wholestic view on the country living and converting the two families to the truth about the country living, are the two visible growth for the Georgia Central Korean SDA Church. 


\section{APPENDIX 1: QUESTIONNAIRE FOR SURVEY REGARDING COUNTRY LIVING}

\section{Before the Workshop}

Please circle the letter of your answer.

1. What the country means to me:

( 1 ) a. isolation from civilization.

$14 \%$ ( 6 ) b. rural district where the houses are not crowded closely together.

(33) c. a location at least 30-50 miles away from the city limit.

( 2 ) d. none of the above or other:

2. Where is the most suitable location to live, especially for families with children?

( 5 ) a. in the vicinity of the denominational institutions.

( 1 ) b. residential areas of the city.

$83 \%$ ( 35 ) c. on a piece of land in a rural area for the home and cultivation of orchards and gardens.

(1) d. none of the above or other:

3. Having considered to move to the country, we should move:

( ) a. immediately.

$95 \%$ ( 40 ) b. as God opens the way, with advice and much prayer.

( 2 ) c. following other families who are moving to the country.

( ) d. none of the above or other: 
4. What is the major reason to move to the country?

( 2 ) a. the country is a very comfortable place to live.

( ) b. growing fruits and vegetables for the purpose of selling.

95\% ( 40 ) c. for character development by physical, mental and spiritual improvement.

( ) d. none of the above or other:

5. What is the final signal for leaving the large cities, preparatory to leaving the smaller ones for retired homes among the mountains or rural areas?

( 4 ) a. when a economic recession strikes.

( 2 ) b. when labor unions strike.

$62 \%$ (26) c. when the National Sunday Law is enforced.

(10) d. none of the above or other:

6. From a religious point of view, what is a characteristic of the modern city?

( 1 ) a. commercial and cultural center.

$93 \%$ ( 39 ) b. hotbed of vice of all kinds.

( 2 ) c. center of modern civilization.

( ) d. none of the above or other:

7. How do you relate salvation to country living?

( 3 ) a. salvation is possible only for those who live in the country these days, for the city is extremely wicked.

$78 \%$ ( 33 ) b. we can't say about individual salvation pertaining to country living or city living.

c. I don't know.

( 6 ) d. none of the above or other: 
8. Why will the large cities be visited by the judgement of God?

( ) a. people in the large cities do not believe in God.

$90 \%$ ( 38 ) b. large cities are hotbeds of iniquities, like Sodom and Gomorrah.

( ) c. God wants to cleanse the large cities.

( 4 ) d. none of the above or other:

9. Should all SDA get out of the cities and move to the country now?

( 6 ) a. yes, definitely.

( 5 ) b. only those who need to.

$71 \%$ ( 30 ) c. there is no fixed rule for everybody.

(1) d. none of the above or other:

10. Ellen White emphasized the city mission. Who should work the city?

( 2 ) a. God's people living in the cities.

( 6 ) b. God's people living in the country.

$74 \%$ ( 31 ) c. God's people living in both the cities and the country.

( 3 ) d. none of the above or other:

11. How are we to warn the cities?

$73 \%$ ( 30 ) a. by establishing outpost centers and memorials.

( 5 ) b. by establishing institutions in the cities.

(6) c. only by the experienced evangelists.

(1) d. none of the above or other:

12. Who did Ellen White say should settle in the cities?

( 2 ) a. those who find jobs in the city.

(6) b. those who are not familiar with country living.

$74 \%$ ( 31 ) c. those who are well grounded in truth.

( 3 ) d. none of the above or other: 
13. Where is the suitable location for our institutions?

( 7 ) a. in the centers of population for evangelism.

$74 \%$ ( 31 ) b. rural districts, in easy access to the cities.

(2) c. among the quiet mountains.

( 2 ) d. none of the above or other:

14. What is the best inheritance parents can give to their children?

( ) a. wealth and fame.

( 3 ) b. knowledge through education.

$90 \%$ ( 38 ) c. a healthy body, sound mind, and noble character.

(1) d. none of the above or other:

15. What are the neccesary factors to be considered before moving to the country?

$45 \%$ ( 19 ) a. family sustenance, proximity to school and church, family garden, etc.

( 2 ) b. how many families are moving to the country.

(20) c. belief that God will provide.

( 1 ) d. none of the above or other: 


\section{APPENDIX 2}

\section{QUESTIONAIRE FOR SURVEY REGARDING COUNTRY LIVING}

\section{After the Workshop}

Please circle the letter of your answer.

1. What the country means to me:

( 1 ) a. isolation from civilization.

$62 \%$ ( 26 ) b. rural district where the houses are not crowded closely together.

(13) c. a location at least 30-50 miles away from the city limit.

( 2 ) d. none of the above or other:

2. Where is the most suitable location to live, especially for families with children?

(4) a. in the vicinity of the denominational institutions.

( 2 ) b. residential areas of the city.

$85 \%$ ( 36 ) c. on a piece of land in a rural area for the home and cultivation of orchards and gardens.

( ) d. none of the above or other:

3. Having considered to move to the country, we should move:

(1) a. immediately.

97\% ( 41 ) b. as God opens the way, with advice and much prayer.

( ) c. following other families who are moving to the country.

( ) d. none of the above or other: 
4. What is the major reason to move to the country?

( ) a. the country is a very comfortable place to live.

( 1 ) b. growing fruits and vegetables for the purpose of selling.

$97 \%$ ( 41 ) c. for character development by physical, mental and spiritual improvement.

( ) d. none of the above or other:

5. What is the final signal for leaving the large cities, preparatory to leaving the smaller ones for retired homes among the mountains or rural areas?

( 2 ) a. when a economic recession strikes.

( 3 ) b. when labor unions strike.

$74 \%$ ( 31 ) c. when the National Sunday Law is enforced.

(6) d. none of the above or other:

6. From a religious point of view, what is a characteristic of the modern city?

( 2 ) a. commercial and cultural center.

$90 \%$ ( 38 ) b. hotbed of vice of all kinds.

( 2 ) c. center of modern civilization.

( ) d. none of the above or other:

7. How do you relate salvation to country living?

( 4 ) a. salvation is possible only for those who live in the country these days, for the city is extremely wicked.

$81 \%$ ( 34 ) b. we can't say about individual salvation pertaining to country living or city living.

( 2 ) c. I don't know.

( 2 ) d. none of the above or other: 
8. Why will the large cities be visited by the judgement of God?

( ) a. people in the large cities do not believe in God.

$93 \%$ ( 39 ) b. large cities are hotbeds of iniquities, like Sodom and Gomorrah.

( 2 ) c. God wants to cleanse the large cities.

( 1 ) d. none of the above or other:

9. Should all SDA get out of the cities and move to the country now?

( 4 ) a. yes, definitely.

( 7 ) b. only those who need to.

$71 \%$ ( 30 ) c. there is no fixed rule for everybody.

( 1 ) d. none of the above or other:

10. Ellen White emphasized the city mission. Who should work the city?

( 1 ) a. God's people living in the cities.

( 1 ) b. God's people living in the country.

$93 \%$ ( 39 ) c. God's people living in both the cities and the country.

( 1 ) d. none of the above or other:

11. How are we to warn the cities?

$83 \%$ ( 35 ) a. by establishing outpost centers and memorials.

( 4 ) b. by establishing institutions in the cities.

( 2 ) c. only by the experienced evangelists.

( 1 ) d. none of the above or other:

12. Who did Ellen White say should settle in the cities?

( 3 ) a. those who find jobs in the city.

(1) b. those who are not familiar with country living.

$90 \%$ ( 38 ) c. those who are well grounded in truth.

( ) d. none of the above or other: 
13. Where is the suitable location for our institutions?

( 3 ) a. in the centers of population for evangelism.

$90 \%$ ( 38 ) b. rural districts, in easy access to the cities.

( 1 ) c. among the quiet mountains.

( ) d. none of the above or other:

14. What is the best inheritance parents can give to their children?

(1) a. wealth and fame.

( 1 ) b. knowledge through education.

$95 \%$ ( 40 ) c. a healthy body, sound mind, and noble character.

( ) d. none of the above or other:

15. What are the neccesary factors to be considered before moving to the country?

$62 \%$ ( 26 ) a. family sustenance, proximity to school and church, family garden, etc.

( ) b. how many families are moving to the country.

(16) c. belief that God will provide.

( ) d. none of the above or other:

16. Has your perspective and attitude towards moving to the country changed in the past weeks?

( 3 ) a. my desire to move to the country has increased greatly.

$90 \%$ ( 38 ) b. I have a better understanding about the issue.

( ) c. my desire to move to the country has decreased.

( 1 ) d. none of the above or other: 
17. Please write the appropriate answers about yourself.
a. age: ( 7 )20-30, ( 7 )31-40, ( 17 )41-50, ( 11 ) 41-80
b. gender: ( 19 )male, ( 23 )female
c. number of children by age: ( 7 )1-10, ( 20 )11-20
d. marital status: ( 31 )married, ( 5 )single, ( 2 )widowed, ( 4 )divorced
e. number of years you have been an SDA: ( 6 )1-5, ( 10 )6-10, ( 1 ) 11-15, ( 4 ) 16-20, ( 19 )21-50. 


\section{APPENDIX 3 \\ SEVENTH-DAY ADVENTIST SELF-SUPPORTING SCHOOLS IN CURRENT OPERATION}

Source: current list supplied by the Self-Supporting Worker, and $111 / 2 \times 15$ inch, 16-page Monthly Laymen's Missionary Journal, P.O. Box 700, Dodge Center, Minn. 55927. The Self-Supporting Worker is now in its seventh year of publication. Linden McNeilus is founder and contributing editor. 
Self-Supporting Academies and Schools

Alpine Springs Academy

R.R. \#2 Box 102

Fountain City, WI 54629

(608)687-8400

Aspen Valley Youth Ranch

Box 599

Colville, WA 99114

(509) 684-5750

Castle Valley Academy

Box 1120

Moab, UT 84532

(801) 259-7719

Country Garden School

R.R. \#5 Box 184

Walla Walla, WA 99362

(509) 525-4024

Country Haven Academy

R.R. \#1 Box 670

Pasco, WA 99301

(509) 266-4422

Fletcher Academy

Howard Gap Rd.

Fletcher, NC 28732

(704) 684-4751

Groveland Academy

R.R. \#2 Box 454

Groveland, FL 32736

(904) 429-2718

Harbert Hills Academy

R.R. \#2 Box 212

Savannah, TN 38372

(901) 925-3098
Little Creek Academy

1810 Little Creek lane

Knoxville, TN 37922

(615) 690-7861

Laurelbrook School

R.R. \#3 Box 219

Dayton, TN 37321

(615) $775-3339$ or 3336

Mountain State Academy

P.O. Box 82

Pennsboro, WV 26415

Oklahoma Academy

R.R. \#2 Box 655

Harrah, OK 73045

(405)454-2606

Pine Forest Academy

R.R. \#1 Box 35

Chunky, MS 39323-9607

(601) 655-8136

Saragosa Mission

Box 77

Saragosa, TX 79780

(915) $375-2460$

Strawberry Meadows

Box 609

Dodge Center, MN 55927

Stonecave School

R.R. 3 Box 350

Dunlap, TN 37327

(615) $949-4355$ 
Self-Supporting Colleges

Black Hills Health \& Education

Center

Box 1

Hermosa, SD 57744

(605) $255-4101$ or 4579

Weimar Institute

Box 486

Weimar, CA 95736

(916) 637-4111

Hartland College

Box 1

Rapidan, VA 22733

(703) $672-3100$

Specialized Educational Facilities

Schools and Homes for Troubled

Youth

Advent Youth Home 2555 Madrid Way South

St. Petersburg, FL 33712

(813) $866-3677$

School for the Retarded

Cave Springs Home School

Hwy 70

Pegram, TN 37143

(615) 646-6962

Additional Schooling Available

AVT Educational Laboratory:

Creator of auditory, Visual and

tactile aids to learning

R.R. 7 Box 85

Ringgold, GA 30756

Additional Self-Supporting

Ministries
Advent Home Youth Services, Inc. 2555 Madrid Way South

St. Petersburg, FL 33712

(813) 866-3677

Academy of Horticultural Sciences

Box 1089

Moab, UT 84532

(801) $259-7780$

Adventist Frontier Missions

Portag, Banaue View Pt.

Banaue, Ifugao 1203

Philippines

Adventist Frontier Missions

American Sponsors

Clyde Morgan

Box 346

Berrien Springs, MI 49103

American Cassette Ministries

P.O. Box 922

Harrisburg , PA 17108

(717) $652-7000$

(800) $233-4450$

International Children's Care

10413 NE Fourth Plain Blvd.

P.O. Box 3838

Vancouver, WA 98662

(206) 254-5061

(800) ICC-PRAY

Inspiration Books

P.O. Box 8249

Phoenix, AZ 85066-8249

(602) 276-7514

The Layman Foundation

Box 747

Ooltewah, TN 37363

(615) 238-5537 
Mission Projects, Inc.

P.O. Box 2111

Harrison, AR 72601-2111

(206) 863-8807

Three Angels Broadcasting P.O. Box 582

West Frankfort, IL 62896

The "Self Supporting Worker"

Box 700

Dodge Center, MN 55927

(507) 374-6818

Bridge Fellowship Inc.

1650 Pleasant Grove Rd.

Bowling Green, KY 42101

(502) 777-1811

Bessie Allen School

972 Charlie Patterson Rd.

New Market, AL 35761

(205) 379-4061

Colegio Bella Vista

Apartado Postal No. 35

Frontera Comal apa

Chiapas, Mexico 301140

Country Garden School

RR 5 Box 184

Walla Walla, WA 99362

(509) 525-4024

First Copy

36 Central Square

Keene, NH 03431

(603) $352-5234$

Hewitt Research Foundation

P.O. Box 9

36211 SE Sunset View

Washougal, WA 98671

(206) 835-8708
New Life \& Health Ministries

409 Hunter Rd.

Goldendale, WA 98620

(509) 773-3885

United Prison Ministry

Blue Creek Rd.

P.O. Box 8

Verbenal, AL 36091

(205) $755-4744$

(205) 854-4709

Prison Ministries

4995 Estrella Rd.

Paso Robles, CA 93446

(805) 238-1747

Conditioning Centers \& Medical

Institutions

Uchee Pines Institute

RR \#1 Box 443

Seale, AL 36875

(205) $855-4781$ or 4764

Eden Valley Institute

6263 N. Co. Rd. \#29

Loveland, CO 80537-9598

(303) $667-1770$ or 6912

Wildwood Institute

P.O. Box 129

Wildwood, GA 30757

(404) 820-0084

Poland Spring Health Institute

RR \#1 Box 4300

Summit Spring Rd.

Poland Springs, ME 04274

(207) 998-2894

Living Springs Retreat

RR \#3 Bryant Pond Rd.

Putnam Valley, NY 10579

(914) 526-2800 
Son-Lit Acres

1112 Turbyne Rd.

Sweet Home, OR 97386

(503) $367-5430$

Silver Hills Institute

$\mathrm{RR} \# 2$

Lumby, British Columbia

Canada VOE 2G0

Black Hills Missionary College

Box 19

Hermosa, SD 57744

(605) $255-4101$ or 4579

Weimar Institute

Box 486

Weimar, CA 95736

(916) 637-4111

(800) 825-9191

Preventive Health Care \&

Education Center

4027 W. George St.

Banning, CA 92220

(714) $849-4981$

Living Well Health Ranch

P.O. Box 904

Wickenburg, AZ 85358

\section{Lavmen's Training}

ALL OF THE ABOVE PLUS

Mountain Missionary Institute

P.O. Box 807

Harriville, NH 03450

(603) $827-3600$ or 3676

Oak Haven

Pullman, MI 49450
Country Life Outposts

Maranatha Outpost

Route 1 Box 33A

Banks, AL 36005

(205) 243-5919

Country Life Farm

Box 180

Lake Hughes, CA 93532

(805) 724-1881

Country Life Ranch

P.O. Box 147

Wildwood, GA 30757

(404) 820-9323

Country Life Farm

RR 4 Box 57

Newton, NJ 07860

(201) $579-1060$

Nashville Outpost

P.O. Box 98

Pegram, TN 37143

(615) 646-6917

Memphis Outpost

RR 1 Box $127 \mathrm{H}$

Horsby, TN 38044

(901) 376-8883

Country Life Ranch

RR 4 Box 49A

Portage, WI 53901

(608) 742-7504

Country Life Ranch

Aux portes de I'Eden

La Grande Commune

77820 Les Ecrennes

FRANCE

TEL: (1) 60.69.47.48 
Eden Way Farm

RR 1 Box 419

Boones Mill, VA 24065

(703) 334-2842

\section{Bakeries and Stores}

Eden Way Bakery

US 220 North

Rocky Mount, VA 24151

(703) 483-2703

The Country Way Store

79 Brock St.

Sault Sainte Marie, Ontario

CANADA P6A 3B4

(705) 949-1898

\section{Food Stores}

Natural Way Mills, Inc.

RR 2 Box 34

Middle River, MN 56737

(218) 222-3677

Country Life Restaurant \&

Healthfood Store

3752 Ringgold Rd.

Chattanooga, TN 37412

(615) 622-2451

Country Life Natural Foods 4820 District Blvd.

Vernon, CA 90058

Country Life Natural Foods

RR 1

Chisholm, MN 55719

(218) 254-4286

Coutry Life Natural Foods

RR 1

Pullman, MI 49450

(616)236-5011
Aspen Valley Ranch \& Christian Ministries

P.O. Box 599

Colville, WA 99114

(404) 820-2611

Alpine Springs Academy Bakery

RR 2 Box 102

Fountain City, WI 54629

(608) 687-8400; Bakery 8210

The Country Way Store

180 Main St. East

North Bay, Ontario

CANADA P1B $1 \mathrm{~A} 8$

(705) $476-3160$

Country Life Natural Foods

3544 N. Pasadena Avenue

Los Angeles, CA 90031

(213) 221-1166

Country Life Natural Foods

A Division of Mt. Missionary

Institute

P.O. Box 807

Harrisville, NH 03452

(603)827-3389

1-800-332-BULK

Country Life Natural Foods

47238 Reels Mill Road

Frederick, MD 21701

(301)662-8505 
Richardson's Specialty Foods

421 Sherman

Holdredge, NE 68949

(308)995-5451

Nature's Pantry \& Bakery

5700 Ratz Rd.

Hubbard Lake, MI 49747

The Honey Tree

144 East Main St.

Richmond, KY 40475

Eden Way Bakery Farms

The House of Bread

RR 1 Box 923

Boonesville, VA 24065

(703)483-2703 


\title{
APPENDIX 4
}

\section{LECTURE OUTLINE 1}

\author{
Historical Background of the SDA \\ Country Living Movement in North America \\ and Korea
}

I. Anti-Urban Sentiments in Urbanizing America
A. American Frontiers
B. American Liturature Tradition
C. Anti-Urban Religious Organizations
D. Ellen G. White and Country Living

II. Adventist Response in North America
A. Pioneers of SDA
B. North American Commission for Self-Supporting Missionary Work
C. The Assorciation of SDA Self-Supporting Institutions
D. Educational Reform Movement

III. Korean Adventist Country Living Movement
A. Refugee Living in the Mountains (1944-1945)
B. Mountain Living Groups (1959-1970)
C. Country Living (1970's)
D. Cultist, Myung Ho Park (1980-) 


\section{APPENDIX 5 \\ LECTURE OUTLINE 2 \\ Ellen White's Understanding on Country Living and City Living}

I. Country in Scripture and in the Writings of Ellen White
A. God's Original Plan
B. Country Heritage of Noble men in the Bible
C. Aspects of Country
D. Location and distance of country from the city
E. No fixed rule for everybody

II. Conditions in the City
A. Religious and moral condition
B. Physical surroundings
C. Object of God's judgment
D. Eschatological calls
E. Economic Situation of the last days

III. Cautions to Those Who Anticipate Leaving the City
A. Occupation and family sustenance
B. Schools and church
C. Opportunity of witnessing
D. Possibility of gardening 


\section{APPENDIX 6 \\ LECTURE OUTLINE 3}

\section{Balancing Act}

I. City Mission: An Indisputable Counsel
A. History of the early SDA city mission
B. Paradox of SDA mission

1. Country living--ideal for SDA

2. Great Needs of the cities

3. Difficult Situation

II. Resolving the Tension

A. Not either or but both aspects of the cities

1. Both aspects of the cities in Scripture

2. Both aspects of the cities in the writings of Ellen White

B. Not either or but both within and without: Method of the city mission

1. Outpost evangelism

2. City evangelism by settling in the cities 


\section{APPENDIX 7}

\section{GRAPH OF SURVEY STATISTICS}

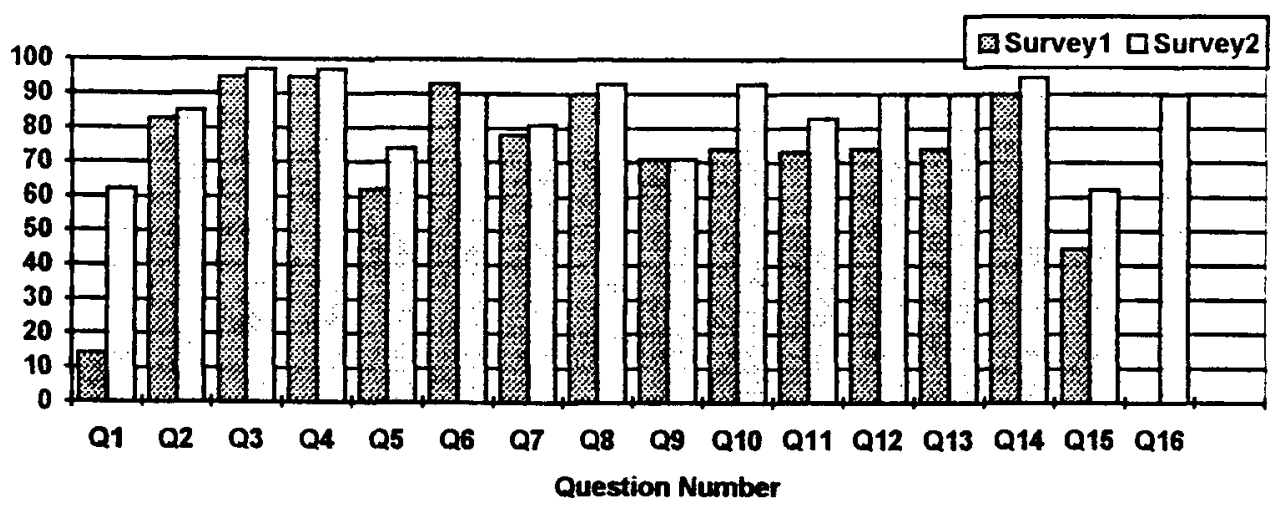

Fig. 1. Graph of Survey 1 and Survey 2 showing change after the workshop.

*Note: Question 16 asks for an opinion and applies only to Survey 2. Ninety percent marked the response, "I have a better understanding about the issue."

Y-axis: Denotes percentage of correct answers

$\mathrm{X}$-axis: Denotes Survey Question number 


\section{BIBLIOGRAPHY}

Actions of the 1978 Annual Council of the General Conference Committee of SDA (Washington, DC), October 10-18, 1978, 23-25, EGWRC-AU.

Amundsen, Wesley. Review of The Christian Home in a Rural Setting, by C. R. McBride. In Ministry, April 1954, 45-46.

Banfield, Warren S. "Why I Moved to the City." Adventist Review, August 23, $1990,12-14$.

Bietz, Arthur L. "Last-day Events: Leaving the Cities." [n.a.;n.d.] Document File 303a, Ellen G. White Research Center, Andrews University, Berrien Springs, MI.

Bode, Carl, ed. The Portable Thoreau. New York: Viking Press, 1947.

Brooks, C. F. "To the Country." Review and Herald, April 30, 1970, 6-7.

Butler, G. I. "Rural Versus City Life." Review and Herald, January 7, 14, 1890.

"Calamities in the Cities." [n.a.;n.d.] Document File 303a, Ellen G. White Research Center, Andrews University, Berrien Springs, MI.

Coney, Betty. "New York Van Ministry." Adventist Review, February 26, 1987, 10-11.

Currie, Alexander. "Observations and a Personal Evaluation of the Wildwood Concept of Self-Supporting Ministry." Term paper, Andrews University, 1976, Document File 357-d, Ellen G. White Research Center. Andrews University, Berrien Springs, MI.

Daniels, A. G. Australian Record. August 13, 1928. 1.

Dyck, Cornelius J., ed. An Introduction to Mennonite History. Scottdale, PA: Herald Press, 1967. 
Eusey, Lee E. "The Solution of Social Problems through Rural Living as Accepted in Seventh-day Adventist Thinking." Term Paper, Michigan State College, 1947. Document File 303A, Ellen G. White Research Center, Andrews University, Berrien Springs, MI.

Fly, James L. "New York City--the Apple of His Eye." Adventist Review, February 19, 1987, 8-10.

Frazee, William D. "Out of the Cities: A Part of the Three Angels' Messages." [n.p.;n.d.] Adventist Heritage Center, Andrews University, Berrien Springs, MI.

- "Wildwood Story," Friday Evening Vesper Service, December 28, 1956. Included as Appendix I of Alexander Currie, "Observations and a Personal Evaluation of the Wildwood Concept of Self-Supporting Ministry," Term Paper, Andrews University, 1976, p. 55, Ellen G. White Research Center, File 357-d. Andrews University, Berrien Springs, MI.

"Garden and Orchard," October 28, 1954. Document File 303a, Ellen G. White Research Center, Andrews University, Berrien Springs, MI.

General Conference of Seventh-day Adventists, Actions of the 1978 Annual Council of the General Conference Committee of SDA, DC, October 10-18, 1978, EGWRC-AU.

General Conference of Seventh-day Adventists, Agenda, Commission on Rural Living," April 10, 1949. Document File 303a, Ellen G. White Research Center, Andrews University, Berrien Springs, MI.

General Conference of Seventh-day Adventists (Washington, DC). Minutes of Meetings of the General Conference Committee, December 9-15, 1945.

General Conference of Seventh-day Adventists (Washington, DC). Minutes of Meetings of the General Conference Committee, August 19-25, 1946.

General Conference of Seventh-day Adventists (Washington, DC). Daily Bulletin of the General Conference Committee, 1888 (No. 8, p. 2). Ellen G. White Research Center, Andrews University, Berrien Springs, MI.

Gish, Ira, and Harry Christman. Madison: God's Beautiful Farm: The E.A. Sutherland Story. Mountain View, CA: Pacific Press Publishing Association, 1974. 
Glaab, Charles N., and A. Theodore Brown. A History of Urban America. New York: MacMillan Company, 1967.

Haynes, Carlyle B. "Adventists and Labor Unions." Review and Herald, February 7, 1946.

$$
\text { Asr: } 25: \cdots:-1 ;
$$

Haynes, Carlyle B. "Out of the Cities." Review and Herald, December 18, 25, 1947.

Hostetler, John A. Amish Society. Baltimore, MD: Johns Hopkins Press, 1963.

Issues: The Seventh-day Adventist Church and Certain Private Ministries. Silver Spring, MD: North American Division, 1992.

Johnsson, William G. "The Greatest Impenitence, the Greatest Need." Adventist Review, February 9, 1984, 13.

_. "Mission to the Cities." Adventist Review, February 19, 1982, 13.

Jones, Alonzo T. Sermon on October 14, 1893, in the Battle Creek Tabernacle. Review and Herald, October 17, 1893.

Juberg, Morten. "A Modern Experiment in Primitive Living." Adventist Review, August 16, 1990, 14-16.

Kim, Sang Do. "Report of Dosari, Ichun Meeting." Church Campass, Seoul, Korea: Korean Signs of the Times Publishing House, 1968.

Kim, Yoo Bok. "A General Survey of the Country Living in the Writings of Ellen White and Its Korean Application." M.A. thesis, Seoul, Korea: Samyook University Press, 1991.

Knight, George. Early Adventist Educators. Berrien Springs, MI: Andrews University Press, 1983.

Kollmorgen, Walter. Culture of a Contemporary Community: The Old Order Amish of Lancaster County, Pennsylvania. Washington DC, United States Department of Agriculture, 1942.

Lee, James M., and David J. Lee. A Compendium on Outpost-to-City Ministry. 4th edition enlarged, rearranged, renumbered. Seoul, Korea: Light and Voice Publishing, 1986.

Lee, Young Lin. Korean Adventist History. Seoul, Korea: Sun Kwang Moon Hwa Sa, 1968. 
Lloyd, Ernest. "Country Living." Review and Herald, September 8, 1966, 4-5.

McBride, C. R. The Christian Home in a Rural Setting. Philadelphia, PA: Judson Press, 1953.

McFarland, W. Margaret. "Memories of E. A. Sutherland." Adventist Heritage Center, Andrews University, Berrien Springs, MI.

McFarland, Wayne. "Rural Living and Self-Supporting Work." The Ministry, July 1947, 31, 46.

_ "Rural Living and Self-Supporting Work." The Ministry, July 1947, 31, 46.

"Minutes of a Sub-committee of the Commission on Rural Living," April 4, 1949. Document File 303a, Ellen G. White Research Center, Andrews University, Berrien Springs, MI.

Morgan, Doug. "Articulating Adventism in the Secular City." Adventist Review, February 26, 1987, 8-10.

North American Division of S.D.A. Church Information System. Monte Sahlin, Project Coordinator, Report 1, Adventist Family Opinion: Demographic Profile, 1990.

Oh, Man Kyoo. Adventist History. Seoul, Korea: Sun Kwang Moon Hwa Sa, 1968.

Olson, Robert W. The Crisis Ahead. Angwin, CA: College Bookstore, 1976.

Oosterwal, Gottfried. "God Loves the Cities." Adventist Review, February 5, 1987, 8-10.

. "How Shall We Work The Cities--From Within?" Ministry, June 1980, 18$22,25$.

Pierson, Robert H. Miracles Happen Every Day. Mountain View, CA: Pacific Press Publishing Association, 1983.

Prescott, W. W. "Country and City." Review and Herald, March 16, 1905.

"Question 72: Is It Time for Us to Move to the Country?" 1990. Ellen G. White Estate Seminar, Washington, DC. Document File 303a, Ellen G. White Research Center, Andrews University, Berrien Springs, MI. 
Ras, Dennis L. "Country Living as an Aid to the Character Development in Youth." Term paper, Andrews University, School of Graduate Studies, 1977.

Document File 303a, Ellen G. White Research Center, Andrews University, Berrien Springs, MI.

"Recommendations Concerning the Manuscript 'From City to Country Living'." By the Literature Committee of the Commission on Rural Living, n.d. Document File 303a, Ellen G. White Research Center, Andrews University, Berrien Springs, MI.

Rice, George E. "Perils and Possibilities." Adventist Review, August 30, 1990, 1011.

Robinson, Dores E. The Story of Our Health Message. Nashville, TN: Southern Publishing Association, 1965.

Ruf, Warren B. "A Historical Study of the Country Living Movement in the Seventh-day Adventist Church." Term paper, Andrews University, Theological Seminary, 1977. Document File 303a, Ellen G. White Research Center, Andrews University, Berrien Springs, Michigan.

Sahlin, Monte. "Unreached City People: Who Are They?" Adventist Review, February 12, 1987, 8-10.

Sandborn, William C. "History of Madison College." Ed.D. thesis, George Peabody College for Teachers, Nashville, 1953.

"Seventh-day Adventists and the Country." [n.a.:n.d.] Document File 303a, Ellen G. White Research Center, Andrews University, Berrien Springs, MI.

Seventh-day Adventist Encyclopedia. 1976 ed. s. v. "Madison Institute"; "Rural Living."

Shea, William H. Selected Studies of Prophetic Interpretation, Daniel and Revelation Committee Series. Vol. 1. Washington, DC: Review and Herald Publishing Association, 1982.

Thoreau, Henry David. Walden and Civil Disobedience. New York: W. W. Norton \& Company, 1966.

Thrash, Calvin L. "Country Living--What It Means to Me." [n.d.] Document File 303a, Ellen G. White Research Center, Andrews University, Berrien Springs, MI. 
VandeVere, Emmett K. The Wisdom Seekers. Nashville, TN: Southern Publishing Association, 1972.

Waggoner, John H. "Chicago Mission." Review and Herald, December 23, 1884.

Watts, Kit. "Balancing Acts." Adventist Review, August 9, 1990, 5.

Way, Richie. "The Paradox of Our Mission." Adventist Review, August 9, 1990, 911.

White, Arthur L. "Adventist Responsibility to the Inner City." Review and Herald, November 5, 1970.

White, Arthur L. "Agricultural Experience of Ellen G. White: Ellen G. White's Personal Interest in Rural Living," 1951. Document File 303a, Ellen G. White Research Center, Andrews University, Berrien Springs, MI.

"Country Living." From Report of the Agricultural and Rural Living Workshop, Berrien Springs, Michigan, December 29-31, 1953. Document File 303a, Ellen G. White Research Center, Andrews University, Berrien Springs, MI.

. Ellen G. White: The Early Elmshaven Years: 1900-1905. Vol. 5. Washington, DC: Review and Herald, 1981.

. Ellen G. White: The Progressive Years: 1862-1876. Vol. 2. Washington, DC: Review and Herald, 1985.

, to J. W. Bothe, Document File 303a, EGWRC-AU.

. "A Shift in Emphasis." Review and Herald, November 12, 1970.

. "A Strategy of Diversion." Review and Herald, November 19, 1970.

White, Arthur L., and E. A. Sutherland. From City to Country Living. Hagerstown, MD: Review and Herald Publishing Association, 1983.

White, Ellen G. The Acts of the Apostles. Mountain View, CA: Pacific Press Publishing Association, 1911.

. The Adventist Home. Hagerstown, MD: Review and Herald Publishing Association, 1980. 
White, Ellen G. "Among the Churches--St. Helena." The Signs of the Times, January 26, 1882, 4.

"Among the Mountains." The Sings of the Times, February 2, 1882, 4-6.

- An Appeal. 1882. No imprint. Ellen G. White published writing on CDROM. Silver Spring, MD: Ellen G. White Estate, 1990.

. "Behold, What Manner of Love." Review and Herald, September 27, 1906.

- Child Guidance. Washington, DC: Review and Herald Publishing Association, 1954.

- Christian Leadership. Washington, DC: Ellen White Estate, Inc., 1985.

- Christ's Object Lessons. Washington, DC: Review and Herald Publishing Association, 1941.

- Colporteur Ministry. Mountain View, CA: Pacific Press Publishing Association, 1953.

- Counsels on Health. Mountain View, CA: Pacific Press Publishing Association, 1957.

- Counsels on Stewardship. Washington, DC: Review and Herald Publishing Association, 1940.

- Counsels to Parents, Teachers, and Students. Mountain View, CA: Pacific Press Publishing Association, 1943.

- Counsels to Parents, Teachers, and Students. Mountain View, CA: Pacific Press Publishing Association, 1943.

- Country Living: An Aid to Moral and Social Security. Washington, DC: Review and Herald Publishing Association, 1946.

- Desire of Ages. Mountain View, CA: Pacific Press Publishing Association, 1940.

- Early Writings of Ellen G. White. Washington, DC: Review and Herald Publishing Association, 1845.

- Education. Mountain View, CA: Pacific Press Publishing Association, 1903. 
White, Ellen G. Evangelism. Washington, DC: Review and Herald Publishing Association, 1970.

- Fundamentals of Christian Education. Nashville, TN: Southern publishing Association, 1923.

- The Great Controversy between Christ and Satan. Mountain View, CA: Pacific Press Publishing Association, 1907.

. "Influence and Importance of Associations." The Signs of Times, September $10,1885,545$.

- 1904. Letter 141, EGWRC-AU; quoted in White and Sutherland, From City to Country Living, 18.

. "Lessons from the Life of Solomon, No. 5 (Order and Organization)." Adventist Review and Sabbath Herald, October 12, 1905, 7.

. Life Sketches of Ellen G. White. Mountain View, CA: Pacific Press Publishing Association, 1943.

- Manuscript Releases. 19 vols. Silver Spring, MD: E. G. White Estate, 1981, 1987, 1990, 1897, 1903, 1900.

. Maranatha: The Lord Is Coming. Washington, DC: Review and Herald Publishing Association, 1976.

- Medical Ministry. Mountain View, CA: Pacific Press Publishing Association, 1963.

. Mind, Character, and Personality. 2 vols. Nashville, TN: Southern Publishing Association, 1977.

. The Ministry of Healing. Mountain View, CA: Pacific Press Publishing Association, 1942.

. "Missionary Work." Review and Herald, September 29, 1891.

- "Missionary Work," 2:521, quoted in idem, Christian Service (Hagerstown, MD: Reivew and Herald Publishing Assn. 1967), 180.

. "Notes of Travel, No. 3 (The Judgments of God on Our Cities)." Adventist Review and Sabbath Herald, July 5, 1906, 7. 
White, Ellen G. Our High Calling. Washington, DC: Review and Herald Publishing Association, 1961.

- Patriarchs and Prophets. Washington, DC: Review and Herald Publishing Association, 1958.

- The Publishing Ministry. Hagerstown, MD: Review and Herald Publishing Association, 1983.

- Prophets and Kings. Mountain View, CA: Pacific Press Publishing Association, 1943.

- Reflecting Christ. Hagerstown, MD: Review and Herald Publishing Association, 1985.

- Selected Messages. 3 vols. Washington, DC: Review and Herald Publishing Association, 1958, 1980.

. "Shall We Colonize Around Our Institutions?" Adventist Review and Sabbath Herald, June 2, 1904, 3.

- Temperance. Mountain View, CA: Pacific Press Publishing Association, 1949.

- Testimonies for the Church. 9 vols. Mountain View, CA: Pacific Press Publishing Association, 1946.

, to Brethren, 1902. Letter 182, EGWRC-AU.

, to Brother and Sister Starr, 1903. Letter 103, 4, EGWRC-AU

, to G. A. Irwin, 1900. Letter 3, EGWRC-AU.

, to George I. Butler, 1903. Letter 200, EGWRC-AU.

, to Elder and Mrs. Haskell, 1900. Letter 90, EGWRC-AU.

, to John H. Kellogg, 1893. Letter 45, EGWRC-AU.

, to Dr. J. H. Kellogg, 1899. Letter 4, EGWRC-AU.

, to J. H. Kellogg, 1900. Letter 45, EGWRC-AU. 
White, Ellen G, to Dr. J. H. Kellogg, 1902. Letter 128, EGWRC-AU. , to Manager of Sanitarium and Food Factory, 1902. Letter 58, EGWRC-AU. , to Steven, 1900. Letter 57, EGWRC-AU. , to Sister Hall, Feb 5, 1904. Letter 63, EGWRC-AU. , to Those in Positions of Responsibility in the Southern Field, 1902. Letter 25, EGWRC-AU.

- Welfare Ministry. Washington, DC: Review and Herald Publishing Association, 1847.

White, Morton, and Lucia White. The Intellectual Versus the City. Cambridge: Harvard University Press, 1962.

Widmer, Myron, "The Challenge of the Cities." Adventist Review, March 12, 1992.

Wilcox, F. M. "Leaving the Cities." Review and Herald, August 27, 1942.

"Wildwood Historical Sketch." Document File 357-d, Ellen G. White Research Center, Andrews University, Berrien Springs, MI.

Wilson, Neal C. "The Challenge of the Cities." Adventist Review, June 7, 1979, 3.

Wilson, Ted, and Gottfried Oosterwal, "How Shall We Work the Cities--From Without?" Ministry, June, 1980, 18-22, 25.

Worley, Robert C. Dry Bones Breathe! Chicago: Center for Their Study of Church Organizational Behavior, 1978. 


\section{VITA}

Born in 1944, I became a Seventh-day Adventist just prior to graduating from high school. I experienced such an overwhelming sense of grace and love of God at the time of my conversion and baptism that I wept much and whole-heartedly dedicated my life to Christ.

As a result of my decision to attend Korean Union College to study theology, I underwent heavy persecution from my family members. In spite of family opposition and a mandatory two-year army service, the Lord helped me to graduate with a B.A. in theology in 1969.

After three years of work in Korea, I immigrated to the United States to further my theological training for the service of God. By the grace of God I finished the M.Div. program at the SDA. Theological Seminary, Andrews University, in 1979.

My first denominational work was to start a new church in Sacramento, California, as a self-supporting worker. After working there for three years, the Sacramento Korean SDA church membership grew to around ninety members. I then moved to the Columbia, South Carolina, Korean Church. More than fifty precious souls were added during my ministry there. My enthusiasm led me to start another new church in Georgia in 1988, and since then I have been pastoring the Georgia Central Korean Church. 